\title{
The Human Cytomegalovirus $\mathrm{U}_{\mathrm{L}} 26$ Protein Antagonizes NF- $\mathrm{B}$ Activation
}

\author{
Chun Mathers, ${ }^{a}$ Xenia Schafer, ${ }^{a}$ Luis Martínez-Sobrido, ${ }^{b}$ Joshua Mungera \\ Department of Biochemistry and Biophysics ${ }^{\mathrm{a}}$ and Department of Microbiology and Immunology, ${ }^{\mathrm{b}}$ University of Rochester Medical Center, Rochester, New York, USA
}

\begin{abstract}
Viral infection frequently triggers activation of host innate immune pathways that attempt to limit viral spread. The NF- $\mathrm{B}$ pathway is a critical component that governs this response. We have found that the human cytomegalovirus (HCMV) $\mathrm{U}_{\mathrm{L}} 26$ protein antagonizes NF- $\kappa B$ activation. Upon infection, an HCMV strain lacking the $U_{L} 26$ gene $\left(\Delta U_{L} 26\right)$ induced the nuclear translocation of the NF- $\kappa$ B RelB subunit and activated expression and secretion of interleukin-6 (IL-6), an NF- $\mathrm{B}$ target gene. The $\Delta \mathrm{U}_{\mathrm{L}} 26$ mutant was also more sensitive to challenge with tumor necrosis factor alpha (TNF- $\alpha$ ), a canonical NF- $\kappa \mathrm{B}$ inducer. Further, expression of $U_{L} 26$ in the absence of other viral proteins blocked NF- $\kappa B$ activation induced by either TNF- $\alpha$ treatment or infection with Sendai virus $(\mathrm{SeV})$. Our results indicate that $\mathrm{U}_{\mathrm{L}} 26$ expression is sufficient to block TNF- $\alpha$-induced NF- $\kappa B$ nuclear

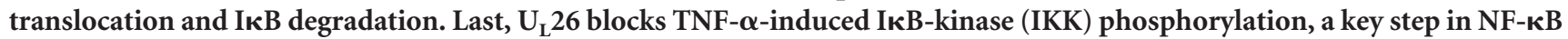
activation. Combined, our results indicate that $\mathrm{U}_{\mathrm{L}} 26$ is part of a viral program to antagonize innate immunity through modulation of NF- $\kappa$ B signaling.
\end{abstract}

\section{IMPORTANCE}

The NF-кB signaling pathway regulates innate immunity, an integral host process that limits viral pathogenesis. Viruses have evolved mechanisms to modulate NF- $\mathrm{B}$ signaling to ensure their replication. HCMV is a major cause of birth defects and disease in immunosuppressed populations. HCMV is known to actively target the NF- $\mathrm{B}$ pathway, which is important for HCMV infection. Our results indicate that the HCMV $U_{L} 26$ gene is a key modulator of NF- $k B$ pathway activity. We find the $U_{L} 26$ gene is both necessary and sufficient to block NF- $\mathrm{B}$ activation upon challenge with antiviral cytokines. Further, $\mathrm{U}_{\mathrm{L}} 26$ attenuates the phosphorylation and activation of a key NF- $\mathrm{B}$ activating kinase complex, IKK. Our study provides new insight into how HCMV targets the NF-кB pathway. Given its importance to viral infection, the mechanisms through which viruses target the NF- $\mathrm{B}$ pathway highlight areas of vulnerability that could be therapeutically targeted to attenuate viral replication.

uman cytomegalovirus (HCMV) is a widely disseminated opportunistic pathogen that causes lifelong infection but rarely results in significant disease in mature, healthy individuals (1). However, congenital HCMV infection causes substantial disease, with approximately one in a thousand children born suffering from permanent HCMV-induced disabilities, including hearing and vision loss, cerebral palsy, and cognitive disability (2-4). Further, HCMV causes serious disease in immunosuppressed populations, including transplant recipients, AIDS patients, and cancer patients receiving immunosuppressive therapies $(1,5)$.

HCMV, a betaherpesvirus, contains a large double-stranded DNA genome of approximately $230 \mathrm{~kb}$, which encodes over 200 open reading frames $(7,8)$. HCMV virions are enveloped and contain an icosahedral capsid which houses the viral genome. A layer of diverse proteins, termed the tegument layer, is located between the capsid and the envelope. Upon initial fusion of the viral envelope with the host-cell plasma membrane, many of these tegument proteins are delivered to the cytoplasm, where they perform a variety of functions that instill an environment conducive to viral replication. These functions include attenuating innate immunity, inducing mitogenic signal transduction pathways, and activating viral gene transcription (9-13).

The protein encoded by the $\mathrm{U}_{\mathrm{L}} 26$ gene is a tegument protein critical for high-titer HCMV replication. Translation of $\mathrm{U}_{\mathrm{L}} 26$ can initiate from one of two in-frame methionines, producing long and short isoforms with molecular masses of 27 and $21 \mathrm{kDa}$, respectively (14). The $\mathrm{U}_{\mathrm{L}} 26$ protein is present throughout the viral life cycle; immediately upon envelope fusion, tegument-derived $\mathrm{U}_{\mathrm{L}} 26$ protein is delivered to the cytoplasm (14), and soon after, de novo $\mathrm{U}_{\mathrm{L}} 26$ is transcribed as an early gene (13). At the onset of infection, the majority of $\mathrm{U}_{\mathrm{L}} 26$ protein localizes to the nucleus (15). As the infectious cycle progresses, $U_{L} 26$ becomes increasingly cytoplasmic and eventually localizes to viral assembly sites (15). Viral mutants containing deletions of the $U_{L} 26$ gene replicate with slower kinetics, produce plaques of reduced size, and grow to lower final titers (15-17). However, the mechanisms through which $\mathrm{U}_{\mathrm{L}} 26$ contributes to $\mathrm{HCMV}$ replication have largely remained elusive.

The NF- $\kappa$ B pathway is a central regulator of a host cell's early response to viral infection. A variety of inflammatory events, including viral infection and exposure to inflammatory molecules, can induce NF-кB's transcriptional activity, which subsequently drives expression of a number of different cytokines, chemokines, and proinflammatory enzymes. The canonical NF- $\mathrm{KB}$ pathway is controlled through a signaling cascade that can initiate upon tu-

\footnotetext{
Received 4 September 2014 Accepted 24 September 2014

Published ahead of print 1 October 2014

Editor: L. Hutt-Fletcher

Address correspondence Joshua Munger, josh.munger@rochester.edu.

Copyright @ 2014, American Society for Microbiology. All Rights Reserved.

doi:10.1128/JVI.02552-14
} 
mor necrosis factor alpha (TNF- $\alpha$ ) receptor binding, resulting in increased linear ubiquitination of NEMO and subsequent assembly and activation of the inhibitor of $\kappa \mathrm{B}$ kinase (IKK) $(18,19)$. Activated IKK phosphorylates the inhibitor of $\kappa \mathrm{B}$ (IKB), resulting in its ubiquitin-mediated degradation $(20,21)$. In the absence of $\mathrm{IKB}$, the RelA and p50 NF- $\mathrm{B}$ subunits are free to translocate to the nucleus, and they subsequently activate transcription of genes containing $\kappa \mathrm{B}$ binding sites (20). Noncanonical NF- $\kappa \mathrm{B}$ signaling occurs upon IKK $\alpha$ activation, which induces nuclear translocation of p52-RelB dimers (22-24). The nature of the transcriptional response induced by these different NF- $\kappa$ B pathways varies depending on the subunit composition and posttranslational modifications of the specific NF- $\mathrm{KB}$ dimers activated (25).

Here, we explored a role for $\mathrm{U}_{\mathrm{L}} 26$ in inhibiting innate immune signal transduction. We find that the $\mathrm{HCMV} \mathrm{U}_{\mathrm{L}} 26$ protein is an inhibitor of NF- $\kappa \mathrm{B}$ activation. Infection with a mutant harboring a deletion of $\mathrm{U}_{\mathrm{L}} 26\left(\Delta \mathrm{U}_{\mathrm{L}} 26\right)$ induces noncanonical NF- $\kappa \mathrm{B}$ activation and fails to block canonical TNF- $\alpha$-induced NF- $\kappa$ B activation. Further, we find that expression of $U_{L} 26$ in the absence of other viral proteins is sufficient to block NF- $\mathrm{B}$ activation upon TNF- $\alpha$ treatment. This inhibition of NF- $\kappa B$ activity appears to result from a $\mathrm{U}_{\mathrm{L}} 26$-mediated attenuation of IKK phosphorylation and subsequent stabilization of IKB. In summary, our results indicate that the $\mathrm{HCMV} \mathrm{U}_{\mathrm{L}} 26$ protein is a viral factor that attenuates the innate immune response through inhibition of $\mathrm{NF}-\kappa \mathrm{B}$ signaling.

\section{MATERIALS AND METHODS}

Cell culture, viruses, and chemicals. MRC5 fibroblasts (passages 23 to 29) were cultured in Dulbecco's modified Eagle medium (DMEM; Invitrogen) supplemented with $10 \%$ fetal bovine serum. The wild-type (WT) HCMV strain used in this study was BADwt, a bacterial artificial chromosome (BAC) clone of $\operatorname{Ad} 169(26,27)$. The $\Delta \mathrm{U}_{\mathrm{L}} 26$ mutant in these studies is a BADwt derivative that was previously described $(15,28)$. Viral stocks were prepared through combining clarified infected cell medium $(3,000 \times g)$ with the remaining clarified infected-cell lysate. For the lysate, the scraped cells were resuspended in $5 \mathrm{ml}$ of infected media, sonicated, and clarified through centrifugation at $3,000 \times g$. Titers of all stocks were determined by plaque assay. For all infections, cells were grown to a confluence of $\sim 3.2 \times 10^{4}$ cells per $\mathrm{cm}^{2}$ prior to infection. Once confluent, medium was removed and serum-free medium was added for $24 \mathrm{~h}$. In all infections, viral inocula were added to cells for a 2-h adsorption period and then the viral inocula were aspirated. For all experiments at a multiplicity of infection (MOI) of 3.0, the extent of infection was monitored through analysis of either green fluorescent protein (GFP) fluorescence (for the $\Delta \mathrm{U}_{\mathrm{L}} 26$ mutant that expresses GFP in place of $\mathrm{U}_{\mathrm{L}} 26$ [15]) or through the appearance of HCMV's distinctive cytopathic effect. In either case, based on these measures, infection at an MOI of 3.0 resulted in $\sim 100 \%$ infection rates. In experiments utilizing UV-irradiated virus, the viral inocula were exposed to $254-\mathrm{nm}$ light at 0 or $1,920 \mathrm{~mJ} / \mathrm{cm}^{2}$ with a model 2400 Stratalinker UV cross-linker prior to infection. TNF- $\alpha$ was purchased from Sigma, and alpha interferon (IFN- $\alpha$ ) was purchased from PBL Assay Science.

Plaque formation assay. Serum-starved confluent MRC5 fibroblasts were treated with TNF- $\alpha$ or IFN- $\alpha$ at various concentrations in 12-well dishes. The cells were then incubated at $37^{\circ} \mathrm{C}$ for $4 \mathrm{~h}$ prior to infection. After removal of the cytokine-containing medium, a fixed number of PFU from freshly thawed virus stocks was seeded. The infection was followed by a conventional plaque assay gel overlay. At 10 days postinfection (dpi), the number of plaques in each well was counted. The number of plaques at each cytokine concentration was plotted as a percentage of the non-cytokine-treated control. Linear or exponential regression analysis was subse- quently performed using Origin 8 . The resulting best-fit curves were utilized to extrapolate $50 \%$ inhibitory concentrations $\left(\mathrm{IC}_{50}\right)$.

Confocal microscopy. For analysis of endogenous RelA, RelB, and IRF3 localization, serum-starved MRC5 fibroblasts were grown on glass coverslips. For RelA analysis, TNF- $\alpha$ was added at $48 \mathrm{~h}$ postinfection (hpi) for $1 \mathrm{~h}$. At various time points postinfection, cells were washed once with phosphate-buffered saline (PBS), fixed with $2 \%$ paraformaldehyde in PBS for $20 \mathrm{~min}$, washed three times with PBS, permeabilized with $0.1 \%$ Triton $\mathrm{X}-100$ and $0.1 \%$ SDS for $15 \mathrm{~min}$, and washed twice with PBS containing $0.05 \%$ Tween 20 . For IRF3, at $6 \mathrm{hpi}$, cells were fixed and permeabilized. Cells were subsequently blocked by overnight incubation in PBS containing 2\% bovine serum albumin (BSA), 5\% goat serum, $5 \%$ human serum, and $0.3 \%$ Triton $\mathrm{X}-100$. Cells were incubated with primary antibody to RelA (C-20; Santa Cruz) or RelB (C-19; Santa Cruz), diluted in PBS plus $0.05 \%$ Tween 20 for $1 \mathrm{~h}$, washed with PBS containing $0.01 \%$ Tween 20 three times, incubated with fluorochrome-conjugated anti-rabbit secondary (Invitrogen) antibody for $1 \mathrm{~h}$, and washed three times in the same buffer lacking antibody. Coverslips were mounted in SlowFade Gold antifade reagent (Molecular Probes) and DAPI (4',6' -diamidino-2-phenylindole). Confocal images were captured with an FV1000 Olympus laser scanning confocal microscope. All images were captured under identical confocal settings.

For confocal analysis of endogenous RelA with $\mathrm{U}_{\mathrm{L}} 26$ transfection, 293T cells were transfected with either $2 \mu \mathrm{g}$ pAC empty vector or $2 \mu \mathrm{g}$ pAC-UL26 expression plasmid using Oligofectamine (Invitrogen). At 24 $\mathrm{h}$ posttransfection, cells were treated with $10 \mathrm{ng} / \mathrm{ml} \mathrm{TNF}-\alpha$ for $24 \mathrm{~h}$. Cells were washed once with PBS, fixed, permeabilized, and blocked as indicated above prior to immunostaining and confocal analysis. For confocal analysis of RelA and IRF3, 30 to $40 \%$ confluent 293 T cells were cotransfected with $2 \mu \mathrm{g}$ of either pCAGGS GFP-RelA or pEGFP-C1-hIRF3 and 2 $\mu \mathrm{g}$ of pAC empty vector or pAC-UL26 expression plasmid. At $24 \mathrm{hpi}$, cells were treated with $10 \mathrm{ng} / \mathrm{ml} \mathrm{TNF}-\alpha$ for $24 \mathrm{~h}$. Cells were then washed once with PBS, fixed, permeabilized, and blocked as indicated above prior to immunostaining and confocal analysis. The IRF3 (17C2) antibody was purchased from KeraFAST.

For confocal analysis of RelA and IRF3 at various times post-TNF- $\alpha$ treatment, 30 to $40 \%$ confluent $293 \mathrm{~T}$ cells were cotransfected with $2 \mu \mathrm{g}$ of either pCAGGS GFP-p65 or pEGFP-C1-hIRF3 and $2 \mu \mathrm{g}$ of pAC empty vector or pAC UL26 overexpression plasmid. At $24 \mathrm{hpi}$, cells were treated with $10 \mathrm{ng} / \mathrm{ml}$ TNF- $\alpha$ for various time periods. GFP-positive cells were counted using a Nikon Eclipse TE200 microscope. The percentage of cells containing nuclear GFP was calculated in comparison to the total number of cells that contained detectable GFP.

NF- $\mathbf{B}$ and IRF3 luciferase assays. TNF- $\alpha$ or Sendai virus $(\mathrm{SeV})$ induction of the NF-кB-dependent reporter plasmid pNF-кB-FF (RelAspecific vector) was done as described previously (29). SeV induction of the IRF3-dependent reporter plasmid (p55C1B-FF) was described previously (30). Briefly, 30 to $40 \%$ confluent $293 \mathrm{~T}$ cells in 6-well plates were cotransfected using calcium phosphate (Stratagene) with $1 \mu \mathrm{g}$ of pNFкB-FF or $1 \mu \mathrm{g}$ p55C1B-FF, $1 \mu \mathrm{g}$ of pAC empty vector, or $1 \mu \mathrm{g}$ pAC $\mathrm{U}_{\mathrm{L}} 26$ overexpression vector $(0.25,0.5$, or $1.0 \mu \mathrm{g}$ for the dose-dependent assay) and $1 \mu \mathrm{g}$ of an expression plasmid encoding Renilla luciferase (RL) under the control of a simian virus 40 promoter (pSV40-RL) to normalize transfection efficiencies. For TNF- $\alpha$-mediated NF- $\kappa B$ activation experiments, cells were treated $24 \mathrm{~h}$ posttransfection with $10 \mathrm{ng} / \mathrm{ml} \mathrm{TNF}-\alpha$ for $24 \mathrm{~h}$, before harvesting for analysis of luciferase activity. For SeV infections, cells were mock or $\mathrm{SeV}$ infected $(\mathrm{MOI}=3.0)$ for $1 \mathrm{~h}$ at room temperature in $1 \times \mathrm{PBS}$, and cell lysates were prepared 16 to $18 \mathrm{~h}$ posttreatment. Luciferase activities were determined using a Promega dualluciferase reporter assay and a Lumicount luminometer (Hewlett Packard). Reporter gene activation was calculated relative to RL activity to control for transfection efficiency.

Real-time qPCR. At various times postinfection, medium was aspirated from cells, total RNA was extracted with TRIzol, and cDNA was synthesized using SuperScript II reverse transcriptase (Invitrogen). Quantitative PCR 
(qPCR) was performed using Fast SYBR green master mix, a model 7500 Fast real-time PCR system, and Fast 7500 software (Applied Biosystems) according to the manufacturer's instructions. Gene expression levels relative to glyceraldehyde-3-phosphate dehydrogenase (GAPDH) were determined according to the $2^{-\Delta \Delta C T}$ method. Specific primer pairs used are as follows: interleukin-6 (IL-6), 5'-AAA-TTC-GGT-ACA-TCC-TCG-ACG-GCA-3' (forward) and 5'-AGT-GCC-TCT-TTG-CTG-CTT-TCA-CAC-3' (reverse); IL-8, 5'-AGA-AAC-CAC-CGG-AAG-GAA-CCA-TCT-3' (forward) and 5' AGA-GCT-GCA-GAA-ATC-AGG-AAG-GCT-3' (reverse); GAPDH, 5' CAT-GTT-CGT-CAT-GGG-TGT-GAA-CCA-3' (forward) and $5^{\prime}$-ATGGCA-TGG-ACT-GTG-GTC-ATG-AGT-3' (reverse).

Protein gel electrophoresis and Western blot analysis. Protein from cell lysates was solubilized in disruption buffer ( $50 \mathrm{mM}$ Tris [pH 7.0], 2\% SDS, 5\% 2-mercapoethanol, and 2.75\% sucrose), separated by either $10 \%$ or 15\% SDS-PAGE, and transferred to nitrocellulose in Tris-glycine transfer buffer. Blots were then stained with Ponceau $S$ to visualize protein bands and ensure equal protein loading. The membranes were blocked in $5 \%$ milk in Tris-buffered saline-Tween 20 (TBST), followed by incubation in primary antibody. After subsequent washes, blots were treated with secondary antibody and protein bands were visualized using the enhanced chemiluminescence (ECL) system (Pierce). The primary antibodies were specific for I $\mathrm{I} \mathrm{B} \alpha$ (Cell Signaling), cellular protein tubulin (Epitomics), phosphor-IKK $\alpha($ Ser176)/IKK $\beta$ (Ser177) (Cell Signaling), total IKK $\alpha / \beta$ (Santa Cruz), NF-кB p50 (H-119; Santa Cruz), p52/P100 (18D10; Cell Signaling), GAPDH (Cell Signaling), and the viral protein $\mathrm{U}_{\mathrm{L}} 26$ (7H19) (31). The secondary antibodies were rabbit polyclonal (Santa Cruz Biotechnology, Inc.) and mouse monoclonal (Abcam). Quantification of the relative abundance of Western blot bands was performed using a ChemiDoc XRS+, a charge-coupled-device (CCD)-based fluorescent quantification system, and ImageLab software, both from BioRad. All Western blot bands were within the linear range of the CCD camera.

ELISA. The quantities of IL- 6 and TNF production in cells were measured by commercial enzyme-linked immunosorbent assay (ELISA) kits (PeproTech) by following the manufacturer's instructions. Values are means plus standard errors (SE; $n=3$ replicates).

Statistical analysis. For all of the Western analyses, a representative blot from at least 3 independent experiments is shown, with the exception of those shown in Fig. 3C and D, which are representative of 2 independent experiments. For all of the Western quantifications, the data are expressed as averages plus standard errors of the means (SEM) from at least two independent biological replicates, which were subsequently analyzed technically in duplicate, i.e., a separate SDS-PAGE gel, blot, and ChemiDoc scan. For all luciferase experiments, the data are representative of at least three biological replicates. Where indicated, the significance of the results was assessed by Student's $t$ test. A $P$ value of $<0.05$ was considered statistically significant.

\section{RESULTS}

A $U_{L}$ 26-deletion mutant activates the noncanonical NF- $\kappa B$ pathway. HCMV appears to have a complex relationship with the NF- $\kappa$ B pathway. Several reports indicate that HCMV can induce NF- $\kappa$ B activity (32-37), while others indicate that HCMV antagonizes NF- $\kappa \mathrm{B}$ activation $(12,38,39)$. To explore whether $\mathrm{U}_{\mathrm{L}} 26$ plays a role in HCMV's modulation of NF- $\kappa \mathrm{B}$ activity, we examined the localization of the RelA NF- $\kappa \mathrm{B}$ subunit after infection with WT HCMV or the $\Delta \mathrm{U}_{\mathrm{L}} 26$ mutant. Consistent with previous reports (35), WT HCMV induced higher levels of RelA than those seen with mock-infected cells (Fig. 1A and B). A similar induction of RelA was observed with $\Delta \mathrm{U}_{\mathrm{L}}$ 26-infected cells (Fig. 1A and B). In canonical NF- $\kappa$ B signaling, RelA dimerizes with NF- $\mathrm{B}$ p50, which is a proteolytic product of a p105 protein precursor (22). The total amounts of $\mathrm{p} 105$ and its processed p50 product were similar between WT and $\Delta \mathrm{U}_{\mathrm{L}} 26$ infection, although both were enhanced in comparison to results with mock-infected cells
(Fig. 1B). Further, there was little difference between WT- and $\Delta \mathrm{U}_{\mathrm{L}} 26$-infected cells with respect to RelA or p50 localization. RelA localized primarily to the cytoplasm (Fig. 1A), where it is transcriptionally inactive, while $\mathrm{p} 50$ localized primarily in the nucleus in both mock- and HCMV-infected cells, regardless of whether $\mathrm{U}_{\mathrm{L}} 26$ was present (Fig. 1C). Thus, our results indicate that deletion of $U_{L} 26$ had little impact on the levels and localization of the canonical NF- $\kappa$ B subunits RelA and p50.

In contrast to RelA, immunofluorescence of RelB differed substantially between WT and $\Delta \mathrm{U}_{\mathrm{L}} 26$ infection (Fig. 1D). At 4 h post$\Delta \mathrm{U}_{\mathrm{L}} 26$ infection, RelB was primarily localized in the nucleus, in contrast to results with WT infection. A similar trend was observed at $48 \mathrm{hpi}$, where RelB immunofluorescence was almost entirely nuclear during $\Delta \mathrm{U}_{\mathrm{L}} 26$ infection in contrast to results with WT infection (Fig. 1D). Infection with both WT and $\Delta \mathrm{U}_{\mathrm{L}} 26$ viruses induced higher RelB levels than those for mock-infected cells, with $\Delta \mathrm{U}_{\mathrm{L}} 26$-infected cells exhibiting an increase in RelB in comparison to results for WT-infected cells (Fig. 1E). This increase was most notable at $48 \mathrm{hpi}$, a time at which RelB levels in $\Delta \mathrm{U}_{\mathrm{L}}$ 26-infected cells were $>2$-fold higher than those in WT-infected cells (Fig. 1E). The NF- $\kappa$ B p100 protein is processed to generate the $\mathrm{p} 52$ subunit which forms the noncanonical NF- $\kappa \mathrm{B}$ dimer with RelB (22). Both WT and $\Delta \mathrm{U}_{\mathrm{L}} 26$ infections induced higher levels of p100 than those for mock-infected cells (Fig. 1E), but the deletion of $U_{L} 26$ had little impact on p52 levels or localization relative to results with the $\mathrm{WT}$ (Fig. $1 \mathrm{E}$ and $\mathrm{F}$, respectively). The finding that $\Delta \mathrm{U}_{\mathrm{L}} 26$ infection induces RelB levels and nuclear translocation suggests that deletion of $\mathrm{U}_{\mathrm{L}} 26$ induces noncanonical $\mathrm{NF}-\kappa \mathrm{B}$ activation.

To examine the potential impact of RelB nuclear translocation during $\Delta \mathrm{U}_{\mathrm{L}} 26$ infection, we analyzed the mRNA levels of IL- 6 and IL-8, genes known to be regulated by NF-кB (40-43). Infection with the $\Delta \mathrm{U}_{\mathrm{L}} 26$ mutant substantially induced accumulation of IL-6 mRNA in comparison to either mock or WT infection (Fig. $2 \mathrm{~A}$ ), which is consistent with increased NF- $\kappa \mathrm{B}$ activation during $\Delta \mathrm{U}_{\mathrm{L}} 26$ infection. In contrast, the levels of IL- 8 mRNA at $24 \mathrm{hpi}$ were actually reduced during $\Delta \mathrm{U}_{\mathrm{L}} 26$ infection, but they were not significantly different between WT and $\Delta \mathrm{U}_{\mathrm{L}} 26$ infection at 48 or 72 hpi (Fig. 2B). To determine whether the induction of IL-6 mRNA observed during $\Delta \mathrm{U}_{\mathrm{L}} 26$ infection correlates to an induction of IL- 6 production, we measured the amount of IL- 6 produced during viral infection. Consistent with the mRNA data, infection with the $\Delta \mathrm{U}_{\mathrm{L}} 26$ mutant significantly increased cellular IL-6 secretion over that seen with WT-infected cells (Fig. 2C). Combined, these results indicate that the deletion of $\mathrm{U}_{\mathrm{L}} 26$ induces RelB nuclear translocation, and the induction of IL- 6 expression and secretion.

A $\mathrm{U}_{\mathrm{L}}$ 26-deletion mutant is more sensitive than the WT to treatment with antiviral cytokines. Since the $\Delta \mathrm{U}_{\mathrm{L}} 26$ mutant induces RelB nuclear translocation indicating noncanonical NF- $\kappa$ B activation, we hypothesized that the $\Delta \mathrm{U}_{\mathrm{L}} 26$ mutant might be sensitive to innate immune challenge. To explore whether $U_{L} 26$ is important for modulation of innate immunity, we compared the abilities of WT HCMV and a $U_{L} 26$-deletion mutant $\left(\Delta U_{L} 26\right)$ to initiate infection after challenge with NF- $\mathrm{B}$ activating cytokines. After cells were treated with various concentrations of TNF- $\alpha$ or IFN- $\alpha$, they were infected with an equivalent number of WT or $\Delta \mathrm{U}_{\mathrm{L}} 26 \mathrm{PFU}$. Increasing concentrations of antiviral cytokines reduced the ability of either virus to initiate a productive infection as assessed by plaque formation, with TNF- $\alpha$ treatment inhibiting 


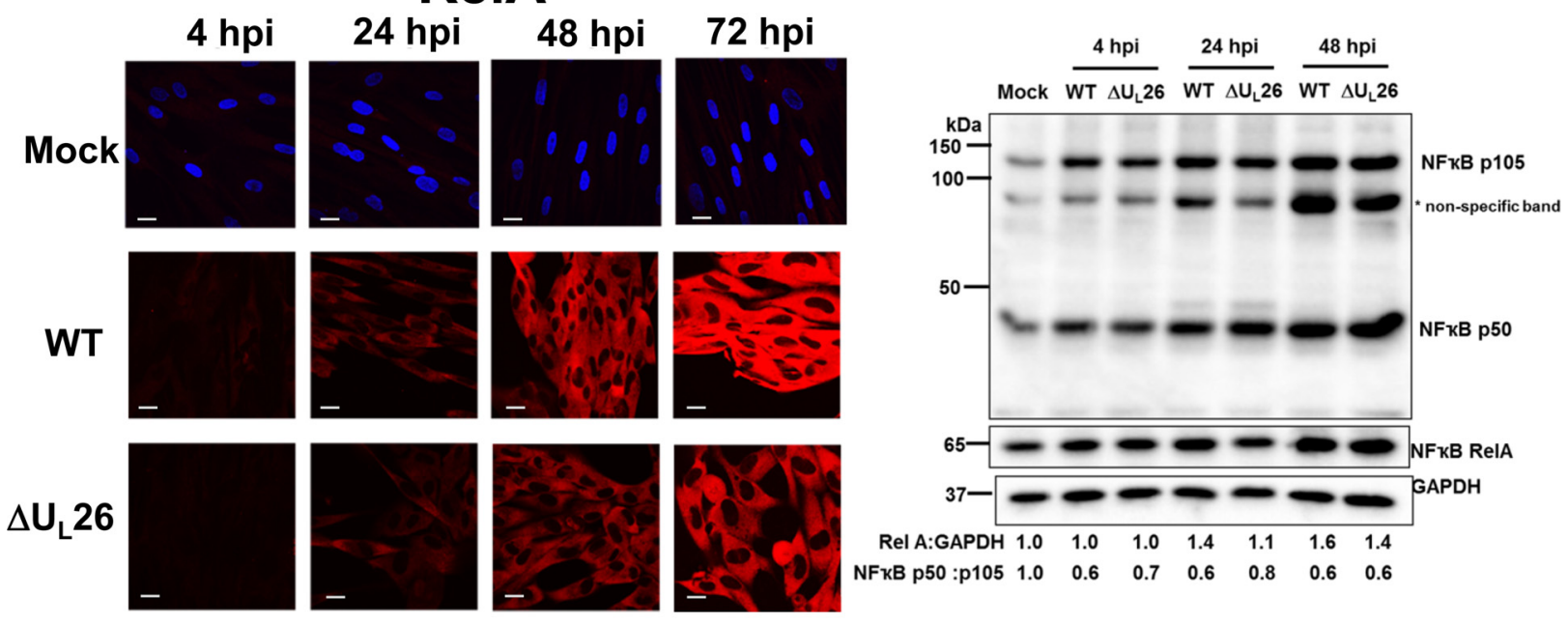

C
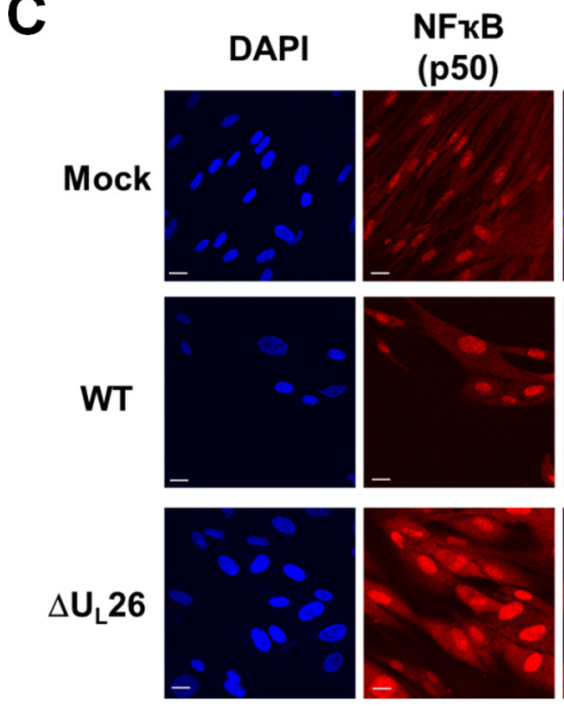

E

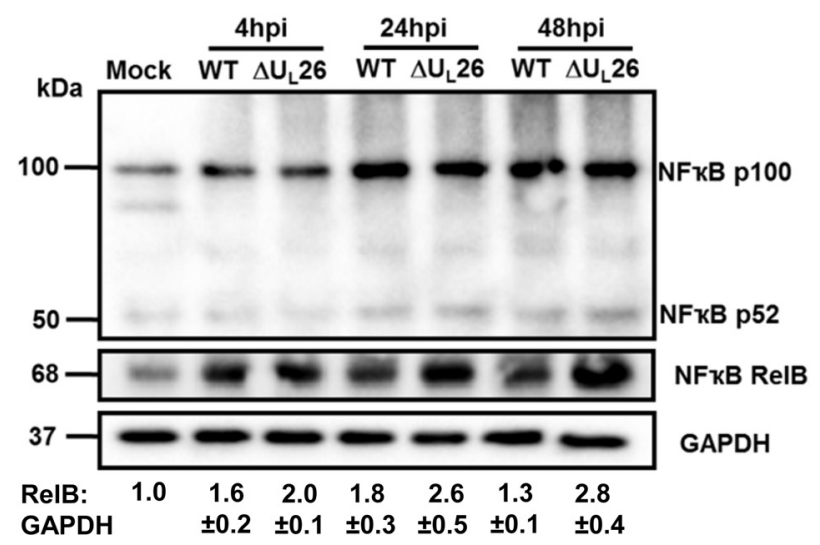

D
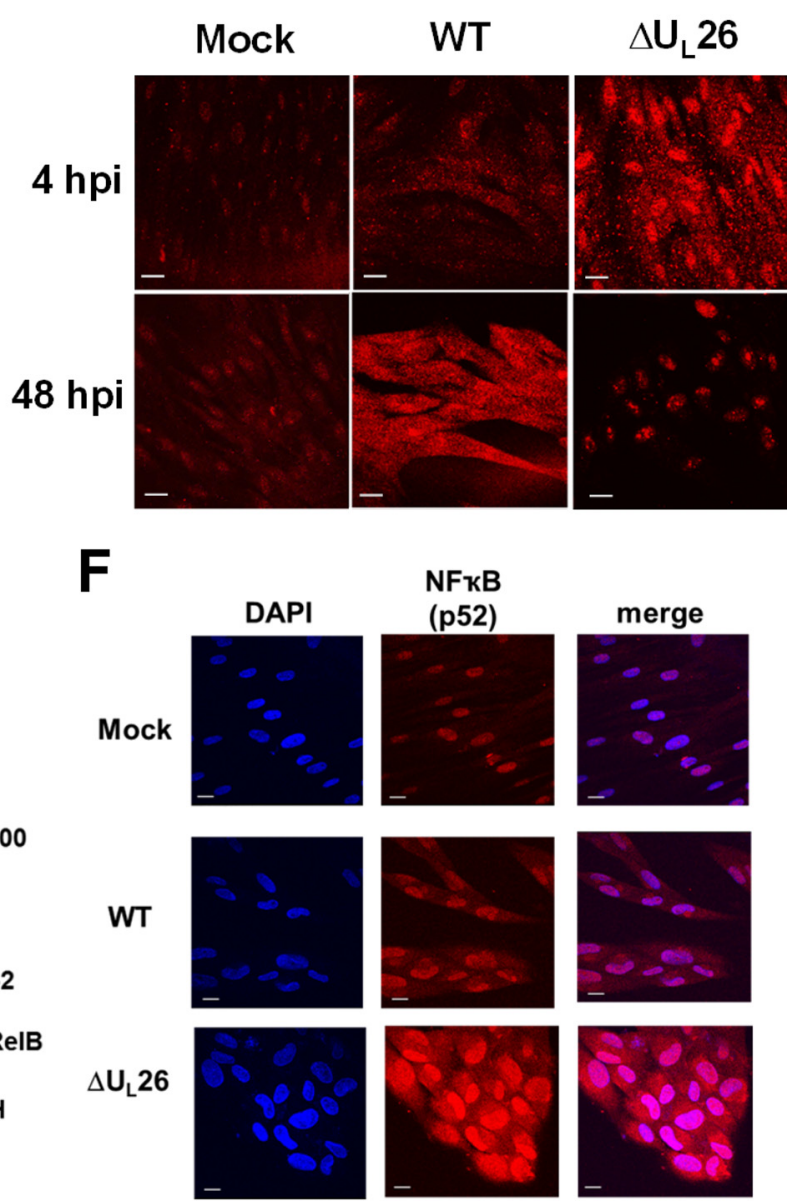

F
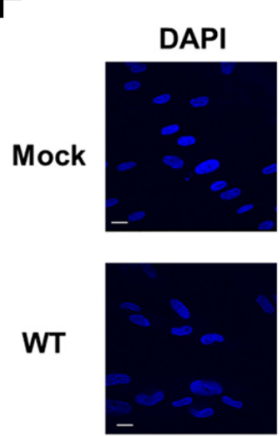

$\Delta \mathbf{U}_{\mathrm{L}} \mathbf{2 6}$

RelB

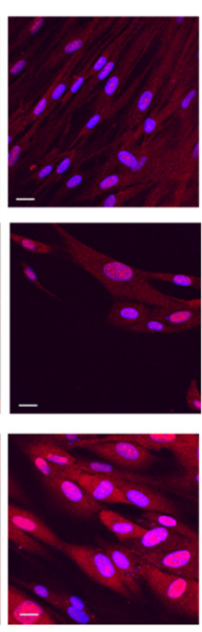

L 

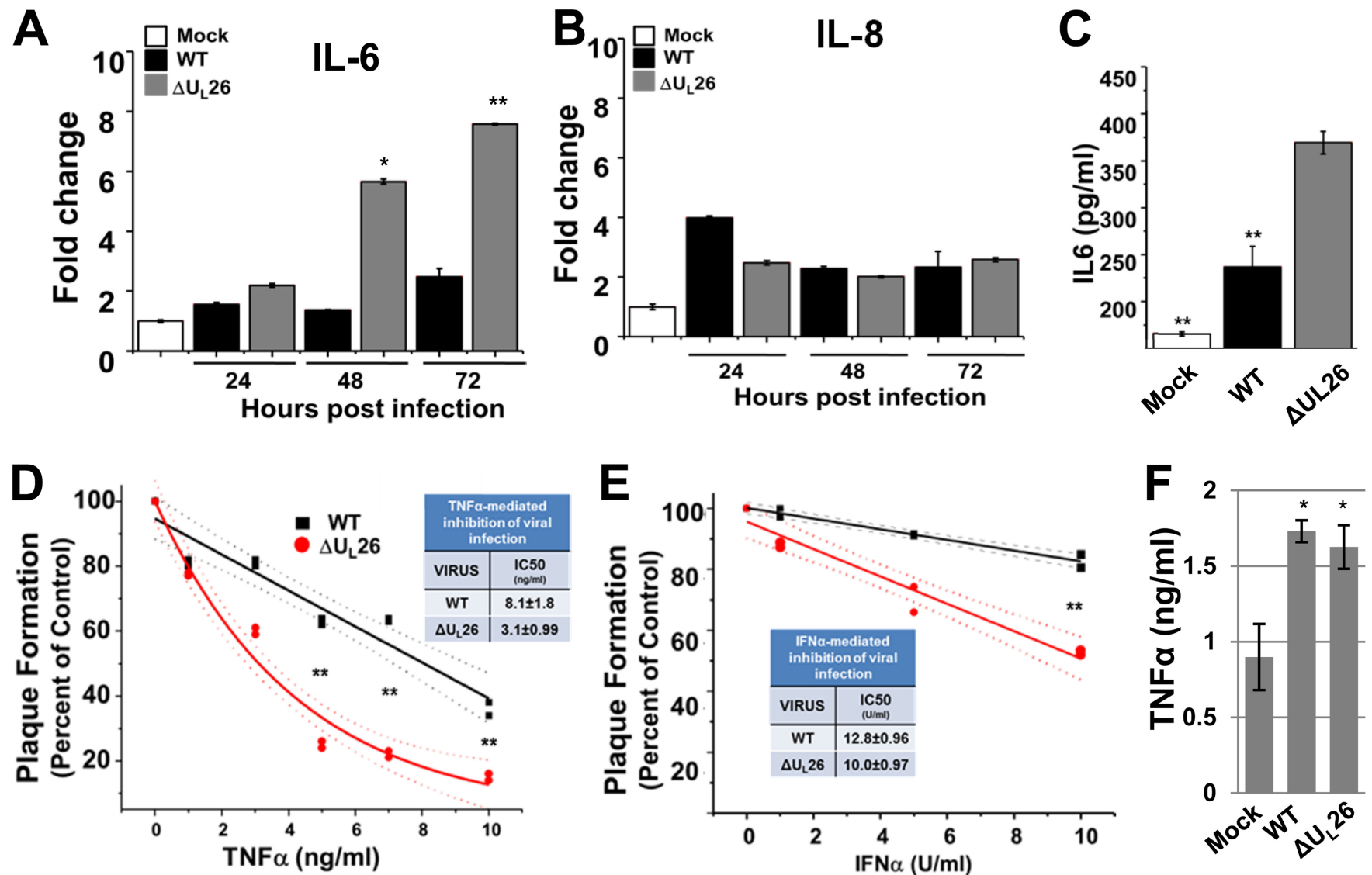

FIG 2 A $U_{\mathrm{L}}$ 26-deletion mutant is more sensitive to treatment with antiviral cytokines. (A and B) MRC5 cells were mock infected or infected with WT or $\Delta \mathrm{U}_{\mathrm{I}} 26$ HCMV (MOI = 3.0) and harvested at the indicated time points. Real-time PCR was performed using primers specific for IL-6, IL-8, or GAPDH $(n \geq 3$, averages \pm SEM; signals normalized to GAPDH and compared to those of mock-infected cells at $24 \mathrm{hpi}$ ). (C) The amount of IL-6 produced was determined at $24 \mathrm{~h}$ after mock, WT, or $\Delta \mathrm{U}_{\mathrm{L}} 26$ infection by ELISA analysis ( $n \geq 3$, averages \pm SEM). (D and E) MRC5 cells were pretreated with different concentrations of TNF- $\alpha$ (D) or IFN- $\alpha$ (E) for $4 \mathrm{~h}$. After removal of the cytokines, a fixed number of PFU from freshly thawed wild-type HCMV (black) or $\Delta \mathrm{U}_{\mathrm{L}} 26$ (red) viral stocks was plated. The percentage of plaque formation at the different doses of cytokine pretreatment is plotted relative to that of the control (untreated). Best-fit curves were plotted and utilized to estimate $\mathrm{IC}_{50}$ (dotted lines represent $95 \%$ confidence intervals of the best-fit curves). (F) The amount of TNF- $\alpha$ produced at $48 \mathrm{~h}$ after mock, WT, or $\Delta \mathrm{U}_{\mathrm{L}} 26$ infection by ELISA analysis (averages \pm SEM). For panels $\mathrm{A}, \mathrm{B}, \mathrm{D}$, and E, statistical comparisons were made between $\mathrm{WT}$ and $\Delta \mathrm{U}_{\mathrm{L}} 26$ infection at the same time point. For panel C, comparisons were made between mock or WT infection versus $\Delta \mathrm{U}_{\mathrm{L}} 26$ infection. For panel F, the comparison was made between WT and mock infection (Student $t$ test; ${ }^{*}, P<0.05$; ${ }^{\star *}, P<0.01$ ).

the establishment of infection at substantially lower concentrations than those for IFN- $\alpha$ (Fig. 2D and E). For both cytokines tested, the $\Delta \mathrm{U}_{\mathrm{L}} 26$ virus was more sensitive to treatment than WT HCMV (Fig. 2D and E). However, the sensitivity of $\Delta \mathrm{U}_{\mathrm{L}} 26$ was more pronounced in response to TNF- $\alpha$ than IFN- $\alpha$. After TNF- $\alpha$ treatment, the $\Delta \mathrm{U}_{\mathrm{L}} 26$ mutant exhibited a $>2.5$-fold decrease in the $\mathrm{IC}_{50}$ of plaque formation $(P<0.01)$ (Fig. $2 \mathrm{D}$ and $\mathrm{E}$ ). To explore the possibility that deletion of $\mathrm{U}_{\mathrm{L}} 26$ might impact TNF- $\alpha$ production, we assayed for TNF- $\alpha$ levels after mock, WT, or $\Delta \mathrm{U}_{\mathrm{L}} 26$ infection. WT HCMV infection induced more TNF-a production than mock-infected cells (Fig. $2 \mathrm{~F}$ ), which agrees with previous reports $(44,45)$. Cells infected with $\Delta \mathrm{U}_{\mathrm{L}} 26$ induced a similar amount of TNF- $\alpha$ (Fig. $2 \mathrm{~F}$ ), suggesting that increased TNF- $\alpha$ production does not explain the increased sensitivity of $\Delta \mathrm{U}_{\mathrm{L}} 26$ virus. Rather, these results suggest that in cells exposed to TNF- $\alpha$, the $U_{L} 26$ protein is important for initiation of infection.

The HCMV $\mathrm{U}_{\mathrm{L}} 26$ protein antagonizes TNF- $\alpha$-induced NF-кB activation. One of the major consequences of TNF- $\alpha$ treatment is NF- $\kappa B$ pathway activation (reviewed in reference 46 ). Given that the $\Delta \mathrm{U}_{\mathrm{L}} 26$ mutant induces noncanonical NF- $\kappa \mathrm{B}$ activ- ity as well as sensitivity to TNF- $\alpha$ treatment, we wanted to explore potential mechanistic links between these phenotypes. We tested the impact of $\mathrm{U}_{\mathrm{L}} 26$ deletion on NF- $\kappa \mathrm{B}$ activity after challenge with TNF- $\alpha$. After TNF- $\alpha$ challenge, RelA localized to the nucleus in mock-infected cells (Fig. 3A). Infection with WT HCMV blocked TNF- $\alpha$-induced RelA nuclear translocation (Fig. 3A). In contrast, $\Delta \mathrm{U}_{\mathrm{L}} 26$-infected cells failed to block TNF- $\alpha$-induced RelA nuclear accumulation (Fig. 3A). While WT HCMV infection blocked RelA nuclear translocation upon TNF- $\alpha$ treatment (Fig. 3A), it failed to block RelB translocation upon TNF- $\alpha$ treatment (Fig. 3B). Interestingly, TNF- $\alpha$ treatment induced more RelB nuclear translocation in WT-infected cells than in mock-infected cells (Fig. 3B). As expected, $\Delta \mathrm{U}_{\mathrm{L}} 26$ infection induced RelB nuclear translocation regardless of whether cells had been treated with TNF- $\alpha$.

As RelA nuclear translocation is induced by IкB degradation, we examined I $\mathrm{B}$ B levels during HCMV infection. In the absence of TNF- $\alpha$ treatment, infection with WT HCMV or $\Delta \mathrm{U}_{\mathrm{L}} 26$ induced an increase in total $\mathrm{I} \kappa \mathrm{B} \alpha$ levels relative to results seen with mock infection (Fig. 3C). However, there was little difference in total 
A

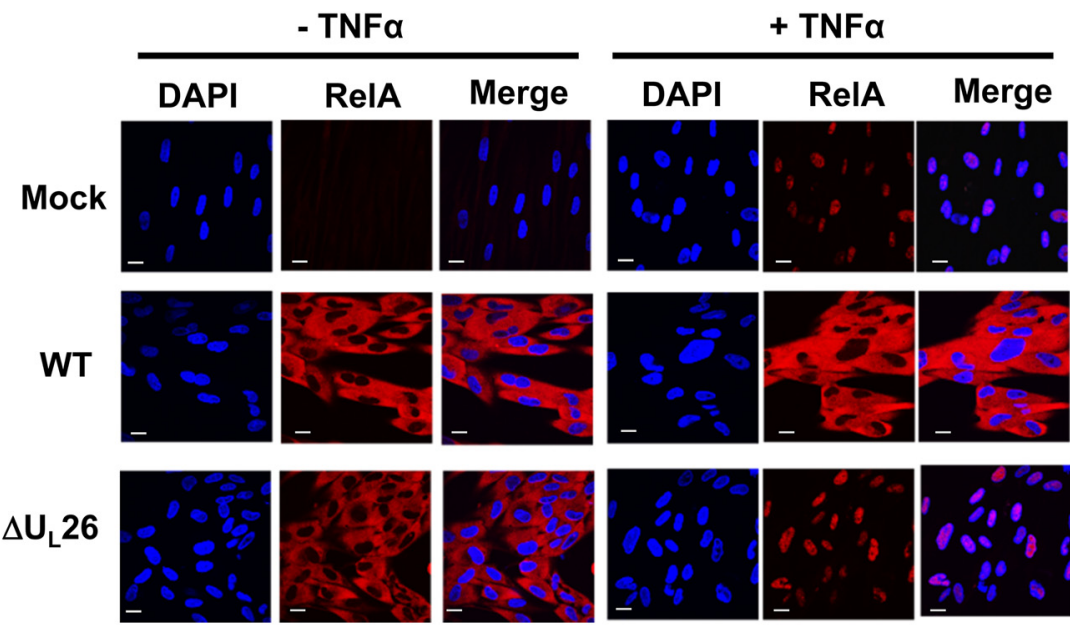

B

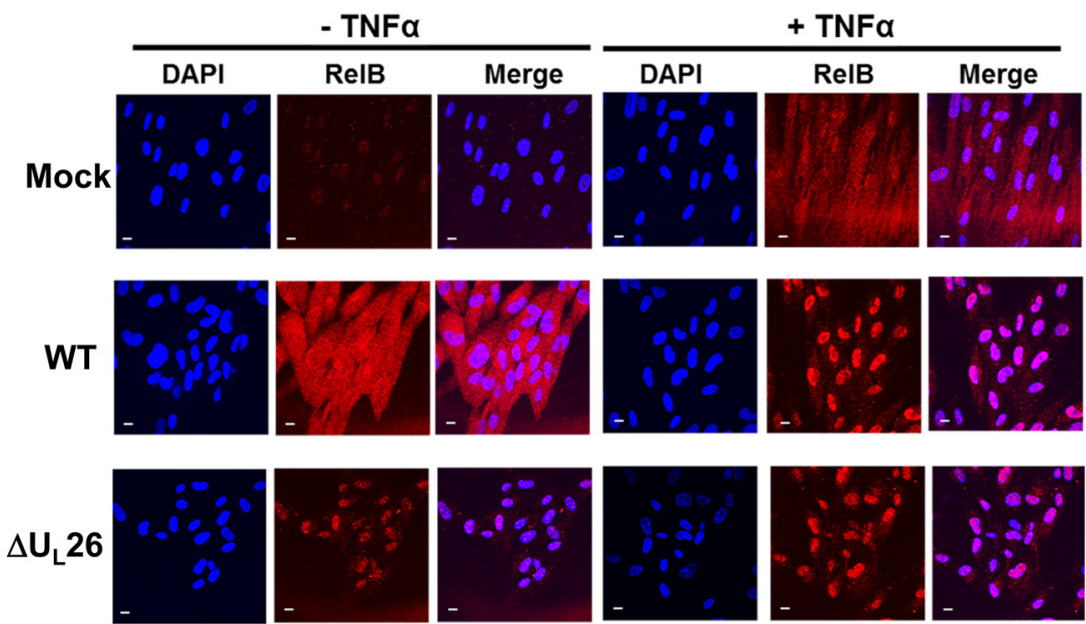

C
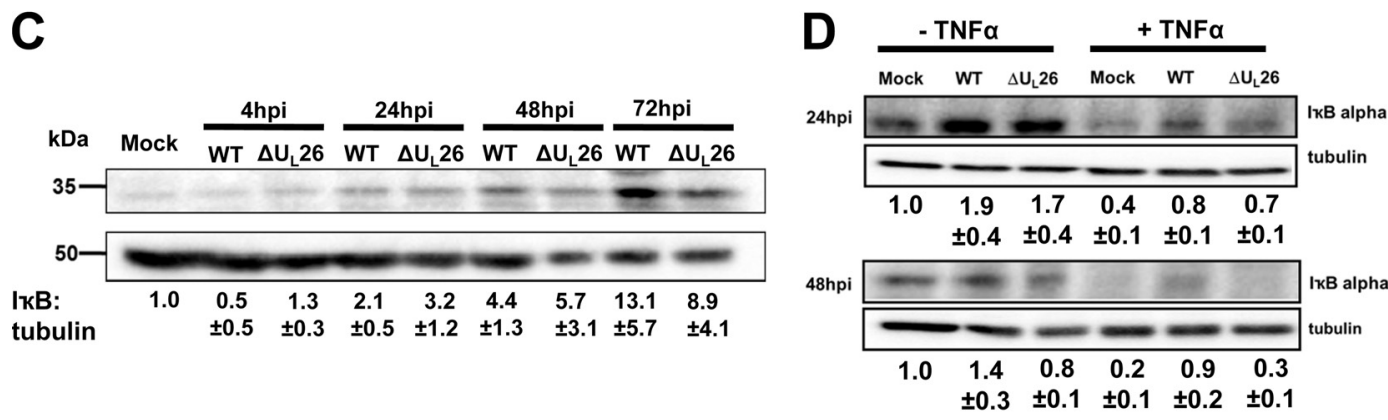

IkB:tubulin

FIG $3 \mathrm{U}_{\mathrm{L}} 26$ is necessary to block TNF- $\alpha$-mediated NF- $\mathrm{B}$ activation. (A) Nuclear translocation of endogenous NF- $\mathrm{kB}$ RelA in HCMV-infected cells upon TNF- $\alpha$ treatment. Confluent MRC5 fibroblasts were mock infected (Mock) or infected with WT or $\Delta \mathrm{U}_{\mathrm{L}} 26 \mathrm{HCMV}(\mathrm{MOI}=3.0)$ ). At 48 hpi, cells were treated with TNF- $\alpha(10 \mathrm{ng} / \mathrm{ml})$ for $1 \mathrm{~h}$, followed by fixation and processing for RelA immunofluorescence (red) and nuclear DAPI staining (blue). Representative images are shown. Bars $=20 \mu \mathrm{m}$. (B) Cells were infected and treated with TNF- $\alpha$ as in panel A, followed by analysis of RelB immunofluorescence (red) and nuclear DAPI staining (blue). Representative images are shown. Bars $=20 \mu \mathrm{m}$. (C) Protein levels of IкB $\alpha$ during mock, WT, or $\Delta \mathrm{U}_{\mathrm{L}} 26$ infection $(\mathrm{MOI}=3.0)$. Cells were harvested for SDS-PAGE and Western analysis at the indicated times (averages \pm SEM). (D) At $24 \mathrm{hpi}$ or $48 \mathrm{hpi}$, cells were treated with TNF- $\alpha$ (10 ng/ml) for

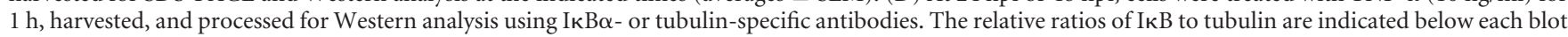
(B and C) (averages \pm SEM). For Western and immunofluorescence experiments, representative images/blots are shown.

I $\mathrm{B} \alpha$ levels in WT- or $\Delta \mathrm{U}_{\mathrm{L}} 26$-infected cells, with the exception of $72 \mathrm{hpi}$, when there was more IкB $\alpha$ present in WT- than in $\Delta \mathrm{U}_{\mathrm{L}} 26-$ infected cells (Fig. 3C). With TNF- $\alpha$ treatment, there was little difference in the amount of IкB $\alpha$ levels between WT- and $\Delta \mathrm{U}_{\mathrm{L}} 26$ - infected cells at $24 \mathrm{hpi}$ (Fig. 3D). In contrast, at $48 \mathrm{hpi}$, TNF- $\alpha$ treatment induced significantly more ІкВ $\alpha$ degradation in $\Delta \mathrm{U}_{\mathrm{L}} 26$-infected and mock-infected cells than in cells infected with WT HCMV (Fig. 3D). These results suggest that the $\mathrm{U}_{\mathrm{L}} 26$ protein 
A

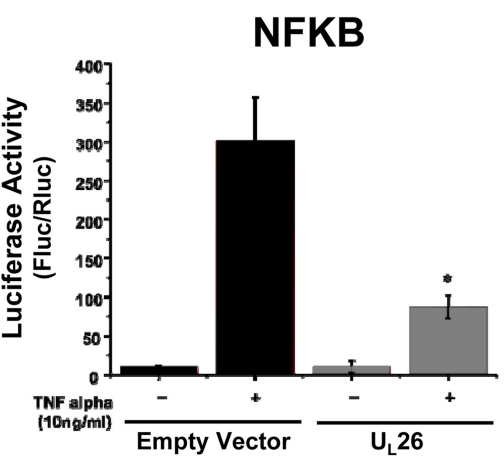

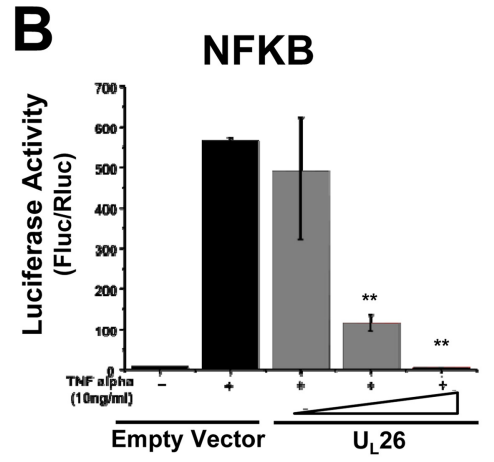

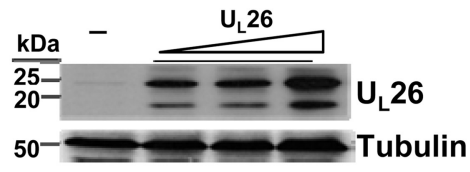

D
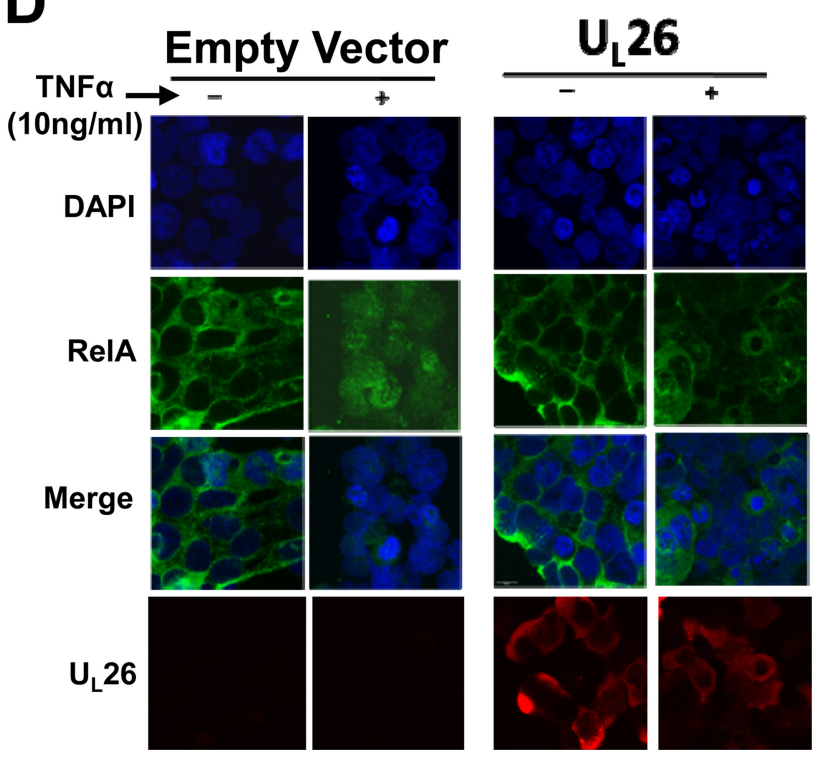

FIG $4 \mathrm{U}_{\mathrm{L}} 26$ is sufficient to bock TNF- $\alpha$-induced NF- $\kappa$ B activation. (A) 293T cells were cotransfected with an NF- $\kappa \mathrm{B}$-dependent luciferase construct, a Renilla expression construct, and equal amounts of either empty vector or $\mathrm{U}_{\mathrm{L}} 26$ overexpression vector $(1 \mu \mathrm{g})$. Twenty-four hours posttransfection, cells were mock or TNF- $\alpha$ treated $(10 \mathrm{ng} / \mathrm{ml})$, incubated for $24 \mathrm{~h}$, harvested, and assayed for firefly luciferase (Fluc) and Renilla luciferase (Rluc) activity. Averages are plotted after normalization to Renilla luciferase activity with SEM ( $\mathrm{n} \geq 3$; $^{*}, P<0.05$; ${ }^{* *}, P<0.01\left[\mathrm{U}_{\mathrm{L}} 26\right.$ versus vector transfected]). (B) 293T cells were transfected and treated as in panel A but with various amounts of $\mathrm{U}_{\mathrm{L}} 26$ as indicated $(0.25,0.5$, and $1.0 \mu \mathrm{g})$. Averages are plotted after normalization to Renilla luciferase activity with SEM $\left(n \geq 3 ;{ }^{*}, P<0.05 ;{ }^{* *}, P<0.01\right)$. The $\mathrm{U}_{\mathrm{L}} 26$ protein levels in transfected $293 \mathrm{~T}$ cells were determined by Western analysis. (C) $293 \mathrm{~T}$ cells were cotransfected with plasmids expressing a GFP-RelA protein with either $\mathrm{U}_{\mathrm{L}} 26$ expression plasmid or an empty vector. At $24 \mathrm{~h}$ posttransfection, cells were treated with TNF- $\alpha$ (10 $\mathrm{ng} / \mathrm{ml}$ ) for $24 \mathrm{~h}$. The subcellular localization of GFP-RelA was assessed under a fluorescence microscope. GFP-RelA nuclear translocation was quantified at various times post-TNF- $\alpha$ treatment $\left({ }^{*}, P<0.01\left[\mathrm{U}_{\mathrm{L}} 26\right.\right.$ versus vector transfected at the same time point]). (D) $293 \mathrm{~T}$ cells were transfected as in panel A. At 24 $\mathrm{h}$ posttransfection, cells were treated with TNF- $\alpha(10 \mathrm{ng} / \mathrm{ml})$ for $24 \mathrm{~h}$, and the subcellular localization of endogenous RelA or $\mathrm{U}_{\mathrm{L}} 26$ was assessed by confocal microscopy. Cellular nuclei were stained with DAPI (blue). Representative images are shown. (E) 293T cells were transfected as in panel A. Twenty-four hours posttransfection, cells were treated with TNF- $\alpha(10 \mathrm{ng} / \mathrm{ml})$ for $24 \mathrm{~h}$ prior to processing for Western analysis with antibodies specific for IкB $\alpha$ or tubulin. The relative ratios of I $\mathrm{B}$ to tubulin are indicated below the blot (averages $\pm \mathrm{SEM}$ ). For all Western and immunofluorescence experiments, representative images/ blots are shown.

is important for HCMV-mediated inhibition of TNF- $\alpha$-induced $\mathrm{NF}-\kappa \mathrm{B}$ activity inasmuch as its deletion results in increased RelA nuclear translocation and ІкB degradation.

While we found the $\mathrm{U}_{\mathrm{L}} 26$ protein to be necessary for HCMVmediated inhibition of TNF- $\alpha$-induced RelA nuclear translocation, we wanted to test whether it was sufficient to block TNF- $\alpha$ induced NF- $\kappa \mathrm{B}$ activity in the absence of other HCMV viral proteins. Expression of $\mathrm{U}_{\mathrm{L}} 26$ blocked TNF- $\alpha$-induced NF- $\kappa \mathrm{B}$-dependent luciferase activity (Fig. 4A). The inhibition of TNF- $\alpha$ induced NF- $\kappa$ B activity was largely $\mathrm{U}_{\mathrm{L}} 26$ dose dependent (Fig. $4 B)$. To determine whether $U_{\mathrm{L}} 26$ expression was sufficient to block NF- $\kappa$ B nuclear translocation upon TNF- $\alpha$ treatment, we examined the localization of GFP-tagged RelA. Shortly after
TNF- $\alpha$ treatment, GFP-RelA migrated to the nucleus in vector control-transfected cells (Fig. 4C). TNF- $\alpha$-induced GFP-RelA translocation was largely blocked by coexpression of the $\mathrm{U}_{\mathrm{L}} 26$ protein (Fig. 4C). Similar results were observed with the analysis of endogenous RelA; $\mathrm{U}_{\mathrm{L}} 26$ attenuated the translocation of endogenous NF- $\kappa$ B to the nucleus upon TNF- $\alpha$ treatment (Fig. 4D). Analysis of $\mathrm{I} \kappa \mathrm{B}$ levels indicated that $\mathrm{U}_{\mathrm{L}} 26$ expression stabilized I $\kappa$ B after TNF- $\alpha$ treatment (Fig. 4E). Taken together, these results indicate that $\mathrm{U}_{\mathrm{L}} 26$ expression is sufficient to stabilize $\mathrm{I} \kappa \mathrm{B}$ and block NF- $\kappa \mathrm{B}$ activation after TNF- $\alpha$ treatment.

The HCMV $\mathrm{U}_{\mathrm{L}} 26$ protein blocks NF- $\mathrm{KB}$ activity induced by Sendai virus infection. To delineate whether $U_{L} 26$-mediated inhibition of NF- $\kappa$ B activation was specific for TNF- $\alpha$, we sought to 


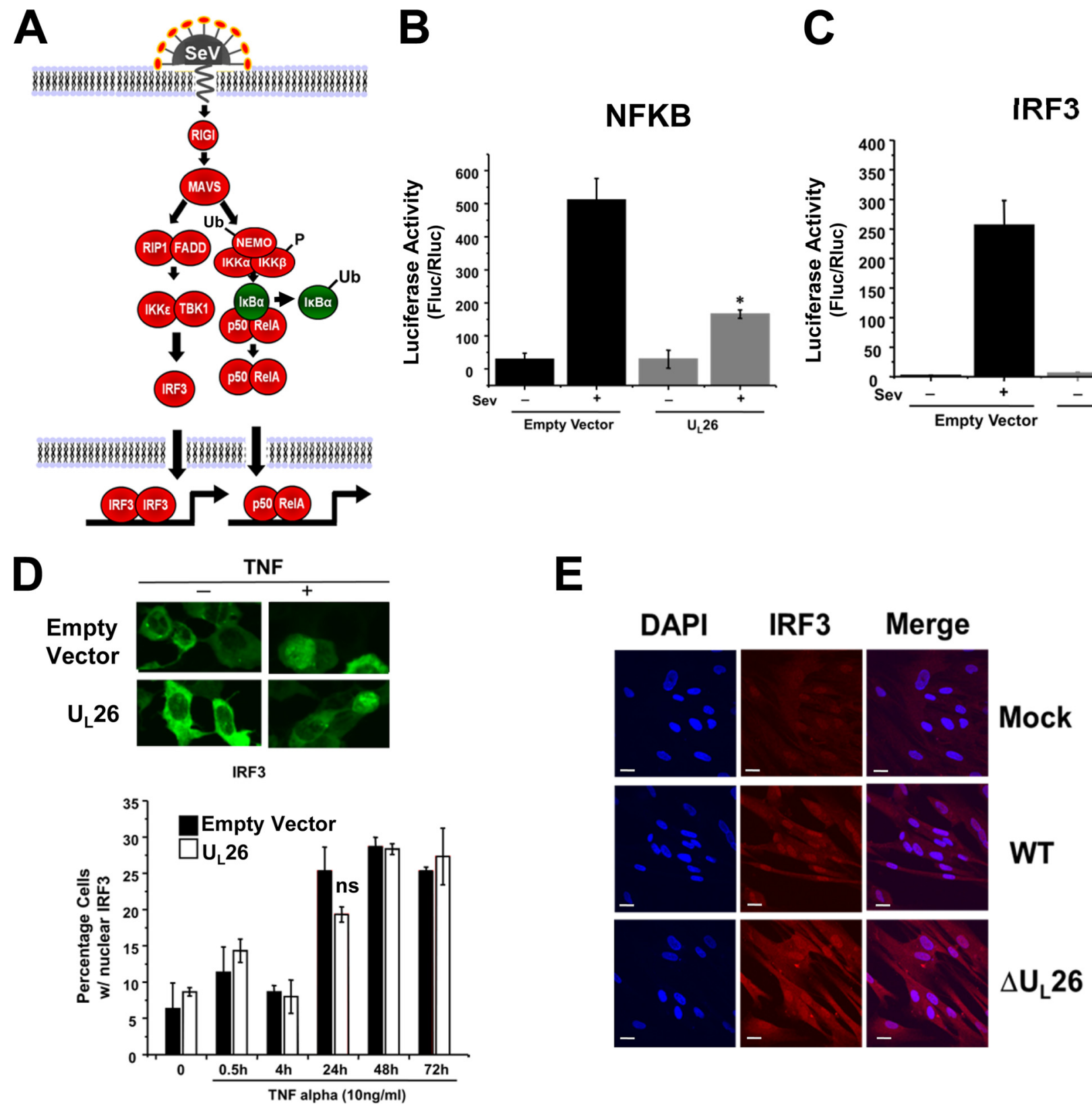

FIG $5 \mathrm{U}_{\mathrm{L}} 26$ blocks Sendai virus-induced NF-кB but not IRF3 activation. (A) Schematic of Sendai virus (SeV)-induced IRF3 and NF- $\mathrm{B}$ activation. Ub, ubiquitination; P, phosphorylation. (B) 293T cells were cotransfected with an NF-кB-dependent luciferase construct, a Renilla expression construct, and equal amounts of either empty vector or $\mathrm{U}_{\mathrm{L}} 26$ overexpression vector $(1 \mu \mathrm{g})$. At $24 \mathrm{~h}$ posttransfection, cells were either mock infected or infected with SeV $(\mathrm{MOI}=3.0)$. Lysates were harvested at $16 \mathrm{hpi}$ and assessed for luciferase activity (averages are plotted after normalization to Renilla luciferase activity (with SEM; $n \geq 3$; $*$, $P<0.05$ [ $\mathrm{U}_{\mathrm{L}} 26$ versus vector transfected]). (C) 293T cells were treated as in panel B, with the exception that an IRF3-dependent luciferase construct was utilized (ns, not significant). (D) 293T cells were cotransfected with a GFP-tagged IRF3 expression plasmid and with either an empty vector or $\mathrm{U}_{\mathrm{I}} 26$ expression plasmid. At $24 \mathrm{~h}$ posttransfection, cells were treated with TNF- $\alpha(10 \mathrm{ng} / \mathrm{ml})$ for $24 \mathrm{~h}$, followed by assessment of GFP-IRF3 subcellular localization by fluorescence microscopy. GFP-IRF3 nuclear translocation was quantified at various times post-TNF- $\alpha$ treatment as indicated (ns, not significant). (E) Confluent MRC5 fibroblasts were mock infected or infected with WT or $\Delta \mathrm{U}_{\mathrm{L}} 26 \mathrm{HCMV}(\mathrm{MOI}=3.0)$. At $6 \mathrm{hpi}$, cells were fixed, permeabilized, and immunostained with antibodies to endogenous IRF3 (red). Cellular nuclei were stained with DAPI (blue). Representative images are shown.

test if $\mathrm{U}_{\mathrm{L}} 26$ inhibited NF- $\mathrm{\kappa B}$ activation in response to other NF- $\kappa B$ inducers. Toward this end, we infected cells with Sendai virus $(\mathrm{SeV})$, which induces both NF- $\mathrm{KB}$ and IRF3 activation through a RIGI-dependent pathway (47) (Fig. 5A). SeV-infected cells exhibited pronounced NF- $\kappa \mathrm{B}$-dependent luciferase activity (Fig. 5B). This induction was substantially reduced by transfection with $\mathrm{U}_{\mathrm{L}} 26$ (Fig. 5B). These results demonstrate that in addition to blocking TNF- $\alpha$-induced NF- $\kappa B$ activation, expression of $\mathrm{U}_{\mathrm{L}} 26$ blocks NF- $\kappa B$ activation mediated by an alternative pathway, indicating that $\mathrm{U}_{\mathrm{L}} 26$ is acting at a conserved downstream point within these pathways.

$\mathrm{SeV}$ infection also resulted in a strong elevation of IRF3-depen- 
dent luciferase activity (Fig. 5C). This induction of IRF3 activity was unaffected by expression of $\mathrm{U}_{\mathrm{L}} 26$ (Fig. 5C). $\mathrm{U}_{\mathrm{L}} 26$ expression also had no effect on TNF- $\alpha$-induced IRF3 nuclear translocation (Fig. 5D). These results suggest that $\mathrm{U}_{\mathrm{L}} 26$-mediated inhibition of NF- $\kappa \mathrm{B}$ signaling occurs downstream of the divergence between TNF- $\alpha$ 's and SeV's stimulation of IRF3 and NF- $\kappa$ B signaling. Further supporting a lack of impact on IRF3 signaling, infection with a $U_{\mathrm{L}}$ 26-deletion mutant did not impact IRF3 localization during HCMV infection (Fig. 5E).

The HCMV $\mathrm{U}_{\mathrm{L}} 26$ protein blocks phosphorylation of the IKK complex. Our findings that $\mathrm{U}_{\mathrm{L}} 26$ blocks NF- $\mathrm{\kappa}$ B activation induced by either TNF- $\alpha$ or SeV infection suggest that $\mathrm{U}_{\mathrm{L}} 26$ blocks NF- $\kappa \mathrm{B}$ activation downstream of where these pathways converge, which occurs at the activation of the IKK complex. In combination with the findings that $\mathrm{U}_{\mathrm{L}} 26$ maintains I $\mathrm{B}$ levels in the presence of TNF- $\alpha$ signaling (Fig. $4 \mathrm{E}$ ), our results suggest that the $\mathrm{U}_{\mathrm{L}} 26$ site of action is either IкB or the IKK complex. The IKK complex is active when $I K K \alpha / \beta$ is serine phosphorylated in its activation loop, which is mediated either through an upstream kinase or through autophosphorylation (48). We examined IKK phosphorylation in WT- or $\Delta \mathrm{U}_{\mathrm{L}} 26$-infected cells. At $48 \mathrm{hpi}$, in the absence of TNF- $\alpha$, WT- and $\Delta \mathrm{U}_{\mathrm{L}} 26$-infected cells exhibited roughly equivalent amounts of IKK phosphorylation (Fig. 6A). The levels of IKK phosphorylation during infection with either virus were increased in comparison to levels seen with mock-infected cells, suggesting a higher level of basal phosphorylation during infection (Fig. 6A). At this same time point, upon TNF- $\alpha$ treatment, WT-infected cells exhibited similar amounts of IKK phosphorylation as untreated cells, consistent with an HCMVinduced block to TNF- $\alpha$-induced IKK phosphorylation and activation. In contrast, mock- or $\Delta \mathrm{U}_{\mathrm{L}} 26$-infected cells showed an increase in IKK phosphorylation upon TNF- $\alpha$ treatment, consistent with IKK activation (Fig. 6A). These results suggest HCMV-mediated attenuation of TNF- $\alpha$-induced IKK phosphorylation requires functional $\mathrm{U}_{\mathrm{L}} 26$. It has been previously reported that HCMV blocks TNF- $\alpha$-induced NF- $\mathrm{B}$ signaling at $48 \mathrm{hpi}$, but not prior to 24 hpi (39). If such is the case, it would suggest that tegument protein delivery, which would include the $\mathrm{U}_{\mathrm{L}} 26$ protein, is not sufficient to block TNF- $\alpha$-induced NF- $\kappa \mathrm{B}$ activation. To further explore this issue, we tested whether WT or UV-irradiated HCMV was sufficient to block TNF- $\alpha$-induced IKK phosphorylation at various times postinfection. As shown in Fig. $6 \mathrm{~B}$, neither WT HCMV nor UV-HCMV was capable of blocking TNF- $\alpha$-induced IKK phosphorylation at 6 hpi. At 24 hpi, TNF- $\alpha$-induced IKK phosphorylation was slightly reduced in HCMV-infected cells relative to TNF- $\alpha$-treated mock-infected cells (Fig. 6B). In contrast, at 48 hpi, WT HCMV infection, but not that with UVirradiated HCMV, resulted in a complete block in IKK phosphorylation (Fig. 6B). These results suggest that HCMV-mediated tegument protein delivery is not sufficient to block TNF- $\alpha$-induced IKK phosphorylation. To determine if $\mathrm{U}_{\mathrm{L}} 26$ expression is sufficient to block TNF- $\alpha$-induced IKK phosphorylation in the absence of other viral proteins, we transfected cells with $U_{L} 26$, treated them with TNF- $\alpha$, and assessed IKK phosphorylation. Expression of the $\mathrm{U}_{\mathrm{L}} 26$ protein in the absence of other HCMV proteins blocked TNF- $\alpha$-induced IKK phosphorylation (Fig. $6 \mathrm{C})$. These results suggest that the $\mathrm{U}_{\mathrm{L}} 26$ protein blocks TNF$\alpha$-induced IKK phosphorylation, thereby attenuating NF- $\kappa$ B signaling.
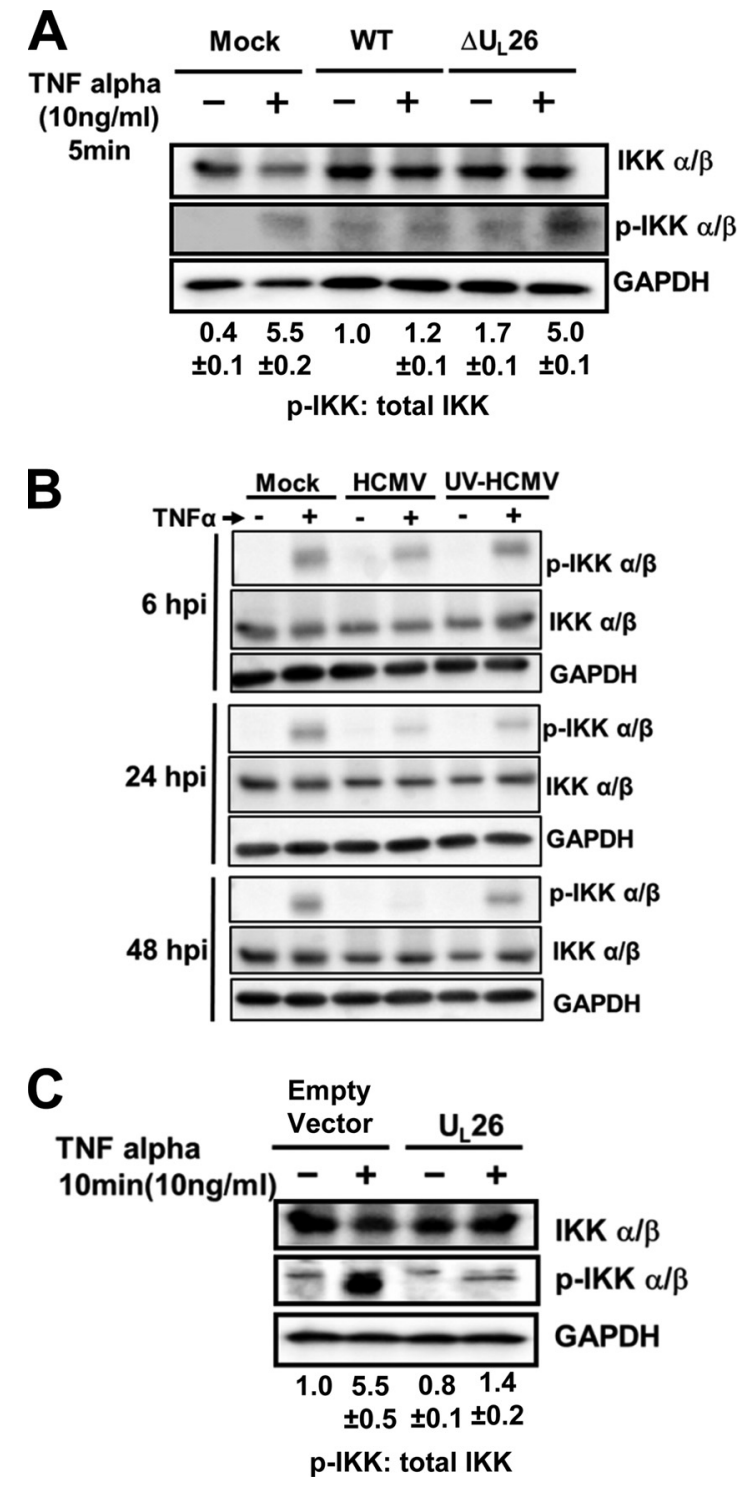

FIG $6 \mathrm{U}_{\mathrm{L}} 26$ blocks IKK phosphorylation. (A) MRC5 cells were mock infected or infected with WT or $\Delta \mathrm{U}_{\mathrm{L}} 26 \mathrm{HCMV}$ (MOI $=3.0$ ). At $48 \mathrm{hpi}$, cells were treated with TNF- $\alpha(10 \mathrm{ng} / \mathrm{ml})$ for $5 \mathrm{~min}$ and then processed for Western analysis using the indicated antibodies. Ratios of pIKK to total IKK are shown under each blot (averages \pm SEM). (B) MRC5 cells were mock infected or infected with mock-irradiated or UV-irradiated WT HCMV (MOI = 3.0), treated with TNF- $\alpha(10 \mathrm{ng} / \mathrm{ml})$ for $5 \mathrm{~min}$ at the indicated hpi, and processed for Western analysis using the indicated antibodies. (C) $293 \mathrm{~T}$ cells were transfected with either an empty vector or a $U_{L} 26$ expression plasmid. Twenty-four hours posttransfection, cells were treated with TNF- $\alpha(10 \mathrm{ng} / \mathrm{ml})$ for $10 \mathrm{~min}$ and then processed for Western analysis using the indicated antibodies. The relative ratios of pIKK to total IKK are indicated below each blot (B and C) (averages \pm SEM).

\section{DISCUSSION}

The NF- $\kappa$ B pathway is central to innate immunity and defense against viruses. NF- $\kappa \mathrm{B}$ activation can induce an antiviral state that limits viral replication; thus, many different viruses attenuate NF- $\kappa$ B signaling as part of their infectious program (49). We have found that the $\mathrm{U}_{\mathrm{L}} 26$ gene blocks many aspects of NF- $\mathrm{\kappa B}$ signaling, including TNF- $\alpha$-induced IKK phosphorylation, IкB degradation, and RelA nuclear translocation. Further, in contrast to WT 
HCMV, a $\mathrm{U}_{\mathrm{L}} 26$ deletion mutant fails to block TNF- $\alpha$-induced NF- $\kappa \mathrm{B}$ activation, and it is more sensitive to challenge with TNF- $\alpha$. $U_{L} 26$ was also sufficient to block NF- $\kappa B$ activation induced by $\mathrm{SeV}$ infection, suggesting that the impact of inhibition of NF- $\kappa \mathrm{B}$ mediated by $\mathrm{U}_{\mathrm{L}} 26$ is not TNF- $\alpha$ specific. In the absence of an exogenous NF- $\kappa B$ inducer, infection with a $U_{L} 26$-deletion $m u-$ tant resulted in the activation of noncanonical NF- $\kappa \mathrm{B}$ signaling, typified by RelB nuclear translocation. Together, our results indicate that the $\mathrm{HCMV}_{\mathrm{L}} 26$ gene is an important viral modulator of NF- $\kappa \mathrm{B}$ signaling.

We found that the $\mathrm{U}_{\mathrm{L}} 26$ protein can impact both the canonical and noncanonical NF- $\mathrm{KB}$ pathways. In the context of HCMV infection, the lack of $\mathrm{U}_{\mathrm{L}} 26$ resulted in RelB nuclear translocation, with concomitant induction of IL-6. Interestingly, in the absence of infection, HCMV IE1 expression has been reported to induce RelB nuclear translocation (50). Given this finding, $\mathrm{U}_{\mathrm{L}} 26$ may be necessary to block RelB nuclear translocation that is induced by IE1 activity during infection. Despite $\mathrm{U}_{\mathrm{L}} 26$ being necessary and sufficient to block RelA nuclear translocation upon TNF- $\alpha$ treatment, infection with $\Delta \mathrm{U}_{\mathrm{L}} 26$ in the absence of TNF- $\alpha$ did not induce RelA nuclear translocation. The lack of RelA nuclear translocation suggests that infection with Ad169 does not activate the canonical NF- $\kappa$ B pathway. Clinical HCMV strains would likely behave differently, as contrary to laboratory adapted strains, they express $\mathrm{U}_{\mathrm{L}} 144$, which has been demonstrated to induce NF- $\mathrm{\kappa} B$ activation $(51,52)$, and $U_{L} 138$, which sensitizes cells to TNF- $\alpha$ treatment $(53,54)$. Additionally, both laboratory and clinical strains encode other factors that antagonize canonical NF- $\mathrm{B}$ signaling. The IE2 protein (IE86) and the major tegument protein pp65 have been reported to inhibit the DNA binding of NF- $\mathrm{BB}$ subunits in the nucleus $(12,55)$. The deletion of the $U_{L} 26$ protein has been shown to impact virion tegumentation (15), which suggests the possibility that defective tegumentation could impact NF-кB-related phenotypes early during infection. However, our experiments indicate that the HCMV-mediated inhibition of TNF- $\alpha$-induced IKK phosphorylation did not occur until 48 hpi and does not occur upon UV inactivation, suggesting that de novo protein synthesis, and not merely delivery of tegument proteins, is required for preventing IKK phosphorylation upon TNF- $\alpha$ treatment. Further, the finding that $\mathrm{U}_{\mathrm{L}} 26$ is sufficient in the absence of other genes to block TNF- $\alpha$-induced NF- $\kappa$ B activation strongly suggests that these TNF- $\alpha$-associated phenotypes are attributable to $\mathrm{U}_{\mathrm{L}} 26$. However, it is possible that different mechanisms are responsible for the two main NF- $\kappa \mathrm{B}$ phenotypes that we have found to be associated with $\Delta \mathrm{U}_{\mathrm{L}} 26$ infection, i.e., increased RelB nuclear translocation and increased TNF- $\alpha$-mediated NF- $\kappa$ B signaling. The RelB nuclear translocation occurs at an earlier time during $\Delta \mathrm{U}_{\mathrm{L}} 26$ infection than does the protection from TNF- $\alpha$ signaling. For the RelB translocation phenotype, the interplay of $\mathrm{U}_{\mathrm{L}} 26$ with other viral factors in the virion could therefore be important. Alternatively, differentially secreted factors present in the initial inoculum, e.g., IL-6, could play a role in the RelB phenotype, as our viral stocks contain conditioned media from the infection responsible for viral stock creation. Future work will need to examine both how different viral factors cooperate to modulate NF- $\kappa \mathrm{B}$ activity and how differential cytokine excretion resulting from $U_{L} 26$ deletion could impact infection.

Both TNF- $\alpha$ treatment and SeV infection induce NF- $\kappa$ B activation, but their upstream signaling components differ. TNF- $\alpha$ induces TRAF assembly with the TNF- $\alpha$ receptors and subsequent recruitment and activation of TAK1, which in turn activates the IKK complex (46). SeV induces NF- $\kappa$ B activation through MAVS/ RIGI-dependent activation of IKK (47). Our finding that $\mathrm{U}_{\mathrm{L}} 26$ blocks NF- $\kappa$ B activation induced by either TNF- $\alpha$ or SeV infection suggests that $U_{L} 26$ likely acts downstream of where these pathways converge. The convergence of these pathways at IKK, combined with our results indicating that $\mathrm{U}_{\mathrm{L}} 26$ blocks induction of IKK phosphorylation, together implicate the IKK complex as the site of $\mathrm{U}_{\mathrm{L}} 26$ modulation. $\mathrm{U}_{\mathrm{L}} 26$-mediated modulation of IKK activity is also consistent with $\mathrm{U}_{\mathrm{L}} 26$ impacting both the canonical RelA and noncanonical RelB pathway, as these two pathways share a dependence on IKK activity.

It has been reported that HCMV induces IKK activity, which is important for viral replication in certain settings (32-34). Consistent with these reports, we find that the basal level of IKK phosphorylation is induced by WT HCMV infection. $\mathrm{U}_{\mathrm{L}} 26$ does not appear to be important for this observed increase in IKK phosphorylation, but rather is only necessary to prevent hyperphosphorylation upon exposure to external NF- $\mathrm{B}$ activators. Together, these studies, in combination with ours, suggest that HCMV may benefit from a controlled activation of IKK, yet has evolved mechanisms to antagonize the robust IKK activity associated with antiviral cytokines. This notion fits into a model of what appears to be a complex relationship between HCMV and NF- $к B$. Several studies have found that extrinsic NF- $\mathrm{B}$ activators inhibit HCMV infection (56-58), while others have found that inhibition of NF- $\kappa \mathrm{B}$ attenuates HCMV infection (32-34). Further, reports indicate that HCMV infection induces NF- $\mathrm{KB}$ transcriptional activity $(35,52)$, while others indicate that HCMV infection blocks NF- $\kappa$ B activation $(12,38,39,55,59)$. On the surface, these reports appear to contradict each other, yet they likely reflect the complexity of NF- $\mathrm{B}$ signaling as well as the multifaceted nature of HCMV-mediated NF- $\kappa$ B modulation. For example, NF- $\mathrm{B}$ activation can induce HCMV promoters $(35,37,60)$ as well as induce expression of host NF- $\kappa \mathrm{B}$ targets that are important for HCMV replication (61). This suggests that limited activation of NF- $\mathrm{B}$ could benefit viral replication. On the other hand, extrinsic activators of NF- $\kappa$ B lead to an antiviral state that is known to inhibit HCMV replication (58), and thus HCMV has evolved gene products to attenuate these pathways. The central question becomes how, mechanistically, HCMV shapes NF- $\kappa$ B transcriptional output to induce proviral NF- $\kappa \mathrm{B}$ targets while attenuating the expression of antiviral NF- $\kappa B$ targets. Our results suggest that $U_{L} 26$ is a key player in this process.

In summary, we find that the $\mathrm{U}_{\mathrm{L}} 26$ gene is an important component in HCMV's effort to modulate NF- $\kappa$ B activity. Diverse viral families attenuate innate immune pathways to enable hightiter replication. This virus-host, innate immune interaction represents a critical evolutionary battleground that shapes the outcome of viral infection. Viral factors, such as $\mathrm{U}_{\mathrm{L}} 26$, that manipulate innate immune responses are therefore potentially attractive targets to limit viral spread. Further, given the central importance of these pathways to infection in general, information garnered from their analysis can potentially be widely applicable to diverse viral families.

\section{ACKNOWLEDGMENTS}

This work was supported by a grant to J.M. from the National Institute of Allergy and Infectious Diseases (R01AI081773). J.M. is a Damon RunyonRachleff Innovator supported (in part) by the Damon Runyon Cancer 
Research Foundation (DRR-09-10). Research in L.M.-S.'s laboratory is funded by NIH grants RO1 AI077719 and R03AI099681-01A1, the NIAID Centers of Excellence for Influenza Research and Surveillance (HHSN266200700008C), and The University of Rochester Center for Biodefense Immune Modeling (HHSN272201000055C).

\section{REFERENCES}

1. Mocarski ES, Shenk T, Pass RF. 2007. Cytomegaloviruses, p 2701-2757. In Knipe DM, Howley PM, Griffin DE, Lamb RA, Martin MA, Roizman BR, Straus SE (ed), Fields virology, 5th ed. Lippincott Williams \& Wilkins, New York, NY.

2. Cannon MJ. 2009. Congenital cytomegalovirus (CMV) epidemiology and awareness. J. Clin. Virol. 46(Suppl 4):S6-S10. http://dx.doi.org/10.1016/j .jcv.2009.09.002.

3. Andrei G, De Clercq E, Snoeck R. 2008. Novel inhibitors of human CMV. Curr. Opin. Investig. Drugs 9:132-145.

4. Grosse SD, Ross DS, Dollard SC. 2008. Congenital cytomegalovirus (CMV) infection as a cause of permanent bilateral hearing loss: a quantitative assessment. J. Clin. Virol. 41:57-62. http://dx.doi.org/10.1016/j.jcv 2007.09.004.

5. Gerna G, Baldanti F, Revello MG. 2004. Pathogenesis of human cytomegalovirus infection and cellular targets. Hum. Immunol. 65:381-386. http://dx.doi.org/10.1016/j.humimm.2004.02.009.

6. Reference deleted.

7. Murphy E, Rigoutsos I, Shibuya T, Shenk TE. 2003. Reevaluation of human cytomegalovirus coding potential. Proc. Natl. Acad. Sci. U. S. A. 100:13585-13590. http://dx.doi.org/10.1073/pnas.1735466100.

8. Stern-Ginossar N, Weisburd B, Michalski A, Le VT, Hein MY, Huang SX, Ma M, Shen B, Qian SB, Hengel H, Mann M, Ingolia NT, Weissman JS. 2012. Decoding human cytomegalovirus. Science 338:10881093. http://dx.doi.org/10.1126/science.1227919.

9. Kalejta RF, Bechtel JT, Shenk T. 2003. Human cytomegalovirus pp71 stimulates cell cycle progression by inducing the proteasome-dependent degradation of the retinoblastoma family of tumor suppressors. Mol. Cell. Biol. 23: 1885-1895. http://dx.doi.org/10.1128/MCB.23.6.1885-1895.2003.

10. Baldick CJ, Jr, Marchini A, Patterson CE, Shenk T. 1997. Human cytomegalovirus tegument protein pp71 (ppUL82) enhances the infectivity of viral DNA and accelerates the infectious cycle. J. Virol. 71:44004408.

11. Bresnahan WA, Shenk TE. 2000. UL82 virion protein activates expression of immediate early viral genes in human cytomegalovirus-infected cells. Proc. Natl. Acad. Sci. U. S. A. 97:14506-14511. http://dx.doi.org/10 $.1073 /$ pnas.97.26.14506

12. Browne EP, Shenk T. 2003. Human cytomegalovirus UL83-coded pp65 virion protein inhibits antiviral gene expression in infected cells. Proc. Natl. Acad. Sci. U. S. A. 100:11439-11444. http://dx.doi.org/10.1073/pnas .1534570100 .

13. Abate DA, Watanabe S, Mocarski ES. 2004. Major human cytomegalovirus structural protein pp65 (ppUL83) prevents interferon response factor 3 activation in the interferon response. J. Virol. 78:10995-11006. http: //dx.doi.org/10.1128/JVI.78.20.10995-11006.2004.

14. Stamminger T, Gstaiger M, Weinzierl K, Lorz K, Winkler M, Schaffner W. 2002. Open reading frame UL26 of human cytomegalovirus encodes a novel tegument protein that contains a strong transcriptional activation domain. J. Virol. 76:4836-4847. http://dx.doi.org/10.1128/JVI.76.10 .4836-4847.2002.

15. Munger J, Yu D, Shenk T. 2006. UL26-deficient human cytomegalovirus produces virions with hypophosphorylated pp28 tegument protein that is unstable within newly infected cells. J. Virol. 80:3541-3548. http://dx.doi .org/10.1128/JVI.80.7.3541-3548.2006.

16. Yu D, Silva MC, Shenk T. 2003. Functional map of human cytomegalovirus AD169 defined by global mutational analysis. Proc. Natl. Acad. Sci. U. S. A. 100:12396-12401. http://dx.doi.org/10.1073/pnas.1635160100.

17. Lorz K, Hofmann H, Berndt A, Tavalai N, Mueller R, SchlotzerSchrehardt U, Stamminger T. 2006. Deletion of open reading frame UL26 from the human cytomegalovirus genome results in reduced viral growth, which involves impaired stability of viral particles. J. Virol. 80: 5423-5434. http://dx.doi.org/10.1128/JVI.02585-05.

18. Haas TL, Emmerich CH, Gerlach B, Schmukle AC, Cordier SM, Rieser E, Feltham R, Vince J, Warnken U, Wenger T, Koschny R, Komander D, Silke J, Walczak H. 2009. Recruitment of the linear ubiquitin chain assembly complex stabilizes the TNF-R1 signaling complex and is re- quired for TNF-mediated gene induction. Mol. Cell 36:831-844. http://dx .doi.org/10.1016/j.molcel.2009.10.013.

19. Tokunaga F, Sakata S, Saeki Y, Satomi Y, Kirisako T, Kamei K, Nakagawa T, Kato M, Murata S, Yamaoka S, Yamamoto M, Akira S, Takao T, Tanaka K, Iwai K. 2009. Involvement of linear polyubiquitylation of NEMO in NF-kappaB activation. Nature Cell Biol. 11:123-132. http://dx .doi.org/10.1038/ncb1821.

20. Chen Z, Hagler J, Palombella VJ, Melandri F, Scherer D, Ballard D, Maniatis T. 1995. Signal-induced site-specific phosphorylation targets I kappa B alpha to the ubiquitin-proteasome pathway. Genes Dev. 9:15861597. http://dx.doi.org/10.1101/gad.9.13.1586.

21. DiDonato J, Mercurio F, Rosette C, Wu-Li J, Suyang H, Ghosh S, Karin M. 1996. Mapping of the inducible IkappaB phosphorylation sites that signal its ubiquitination and degradation. Mol. Cell. Biol. 16:1295-1304.

22. Oeckinghaus A, Ghosh S. 2009. The NF-kappaB family of transcription factors and its regulation. Cold Spring Harb. Perspect. Biol. 1:a000034. http://dx.doi.org/10.1101/cshperspect.a000034.

23. Sun SC. 2012. The noncanonical NF-kappaB pathway. Immunol. Rev. 246:125-140. http://dx.doi.org/10.1111/j.1600-065X.2011.01088.x.

24. Perkins ND. 2007. Integrating cell-signalling pathways with NF-kappaB and IKK function. Nature Rev. 8:49-62. http://dx.doi.org/10.1038 /nrm2083.

25. Smale ST. 2011. Hierarchies of NF-kappaB target-gene regulation. Nat. Immunol. 12:689-694. http://dx.doi.org/10.1038/ni.2070.

26. Rowe WP, Hartley JW, Waterman S, Turner HC, Huebner RJ. 1956. Cytopathogenic agent resembling human salivary gland virus recovered from tissue cultures of human adenoids. Proc. Soc. Exp. Biol. Med. 92: 418-424. http://dx.doi.org/10.3181/00379727-92-22497.

27. Yu D, Smith GA, Enquist LW, Shenk T. 2002. Construction of a selfexcisable bacterial artificial chromosome containing the human cytomegalovirus genome and mutagenesis of the diploid TRL/IRL13 gene. J. Virol. 76:2316-2328. http://dx.doi.org/10.1128/jvi.76.5.2316-2328.2002.

28. Mathers C, Spencer CM, Munger J. 2014. Distinct domains within the human cytomegalovirus $\mathrm{U}(\mathrm{L}) 26$ protein are important for wildtype viral replication and virion stability. PLoS One 9:e88101. http://dx.doi.org/10 .1371/journal.pone.0088101.

29. Rodrigo WW, Ortiz-Riaño E, Pythoud C, Kunz S, de la Torre JC, Martínez-Sobrido L. 2012. Arenavirus nucleoproteins prevent activation of nuclear factor kappa B. J. Virol. 86:8185-8197. http://dx.doi.org/10 .1128/JVI.07240-11.

30. Martínez-Sobrido L, Zuniga EI, Rosario D, Garcia-Sastre A, de la Torre JC. 2006. Inhibition of the type I interferon response by the nucleoprotein of the prototypic arenavirus lymphocytic choriomeningitis virus. J. Virol. 80:9192-9199. http://dx.doi.org/10.1128/JVI.00555-06.

31. Munger J, Bajad SU, Coller HA, Shenk T, Rabinowitz JD. 2006. Dynamics of the cellular metabolome during human cytomegalovirus infection. PLoS Pathog. 2:e132. http://dx.doi.org/10.1371/journal.ppat.0020132.

32. Caposio P, Dreano M, Garotta G, Gribaudo G, Landolfo S. 2004. Human cytomegalovirus stimulates cellular IKK2 activity and requires the enzyme for productive replication. J. Virol. 78:3190-3195. http://dx.doi .org/10.1128/JVI.78.6.3190-3195.2004.

33. Caposio P, Luganini A, Hahn G, Landolfo S, Gribaudo G. 2007. Activation of the virus-induced IKK/NF-kappaB signalling axis is critical for the replication of human cytomegalovirus in quiescent cells. Cell. Microbiol. 9:2040-2054. http://dx.doi.org/10.1111/j.1462-5822.2007.00936.x.

34. Caposio P, Musso T, Luganini A, Inoue H, Gariglio M, Landolfo S, Gribaudo G. 2007. Targeting the NF-kappaB pathway through pharmacological inhibition of IKK2 prevents human cytomegalovirus replication and virus-induced inflammatory response in infected endothelial cells. Antiviral Res. 73:175-184. http://dx.doi.org/10.1016/j.antiviral.2006.10 .001 .

35. Yurochko AD, Kowalik TF, Huong SM, Huang ES. 1995. Human cytomegalovirus upregulates NF-kappa B activity by transactivating the NF-kappa B p105/p50 and p65 promoters. J. Virol. 69:5391-5400.

36. DeMeritt IB, Milford LE, Yurochko AD. 2004. Activation of the NFkappaB pathway in human cytomegalovirus-infected cells is necessary for efficient transactivation of the major immediate-early promoter. J. Virol. 78:4498-4507. http://dx.doi.org/10.1128/JVI.78.9.4498-4507.2004.

37. DeMeritt IB, Podduturi JP, Tilley AM, Nogalski MT, Yurochko AD. 2006. Prolonged activation of NF-kappaB by human cytomegalovirus promotes efficient viral replication and late gene expression. Virology 346 : 15-31. http://dx.doi.org/10.1016/j.virol.2005.09.065.

38. Jarvis MA, Borton JA, Keech AM, Wong J, Britt WJ, Magun BE, Nelson 
JA. 2006. Human cytomegalovirus attenuates interleukin-1beta and tumor necrosis factor alpha proinflammatory signaling by inhibition of NFkappaB activation. J. Virol. 80:5588-5598. http://dx.doi.org/10.1128/JVI $.00060-06$.

39. Montag C, Wagner J, Gruska I, Hagemeier C. 2006. Human cytomegalovirus blocks tumor necrosis factor alpha- and interleukin-1betamediated NF-kappaB signaling. J. Virol. 80:11686-11698. http://dx.doi .org/10.1128/JVI.01168-06.

40. Kunsch C, Lang RK, Rosen CA, Shannon MF. 1994. Synergistic transcriptional activation of the IL- 8 gene by NF-kappa B p65 (RelA) and NF-IL-6. J. Immunol. 153:153-164.

41. Kannabiran C, Zeng X, Vales LD. 1997. The mammalian transcriptional repressor RBP (CBF1) regulates interleukin-6 gene expression. Mol. Cell. Biol. 17:1-9.

42. Kang HB, Kim YE, Kwon HJ, Sok DE, Lee Y. 2007. Enhancement of NF-kappaB expression and activity upon differentiation of human embryonic stem cell line SNUhES3. Stem Cells Dev. 16:615-623. http://dx.doi .org/10.1089/scd.2007.0014.

43. Kunsch C, Rosen CA. 1993. NF-kappa B subunit-specific regulation of the interleukin-8 promoter. Mol. Cell. Biol. 13:6137-6146.

44. Geist LJ, Monick MM, Stinski MF, Hunninghake GW. 1994. The immediate early genes of human cytomegalovirus upregulate tumor necrosis factor-alpha gene expression. J. Clin. Invest. 93:474-478. http://dx.doi .org/10.1172/JCI116995.

45. Smith PD, Saini SS, Raffeld M, Manischewitz JF, Wahl SM. 1992. Cytomegalovirus induction of tumor necrosis factor-alpha by human monocytes and mucosal macrophages. J. Clin. Invest. 90:1642-1648. http: //dx.doi.org/10.1172/JCI116035.

46. Varfolomeev EE, Ashkenazi A. 2004. Tumor necrosis factor: an apoptosis JuNKie? Cell 116:491-497. http://dx.doi.org/10.1016/S0092-8674(04)00166-7.

47. Elco CP, Guenther JM, Williams BR, Sen GC. 2005. Analysis of genes induced by Sendai virus infection of mutant cell lines reveals essential roles of interferon regulatory factor 3, NF-kappaB, and interferon but not tolllike receptor 3. J. Virol. 79:3920-3929. http://dx.doi.org/10.1128/JVI.79.7 .3920-3929.2005.

48. Israël A. 2010. The IKK complex, a central regulator of NF-kappaB activation. Cold Spring Harb. Perspect. Biol. 2:a000158. http://dx.doi.org/10 $.1101 /$ cshperspect.a000158.

49. Hiscott J, Nguyen TL, Arguello M, Nakhaei P, Paz S. 2006. Manipulation of the nuclear factor-kappaB pathway and the innate immune response by viruses. Oncogene 25:6844-6867. http://dx.doi.org/10.1038/sj onc. 1209941

50. Jiang HY, Petrovas C, Sonenshein GE. 2002. RelB-p50 NF- $\kappa$ B complexes are selectively induced by cytomegalovirus immediate-early protein 1: differential regulation of $\mathrm{Bcl}-\mathrm{x}_{\mathrm{L}}$ promoter activity by NF- $\mathrm{\kappa} \mathrm{B}$ family members.
J. Virol. 76:5737-5747. http://dx.doi.org/10.1128/JVI.76.11.5737-5747 .2002 .

51. Poole E, Groves I, MacDonald A, Pang Y, Alcami A, Sinclair J. 2009. Identification of TRIM23 as a cofactor involved in the regulation of NFkappaB by human cytomegalovirus. J. Virol. 83:3581-3590. http://dx.doi .org/10.1128/JVI.02072-08.

52. Poole E, King CA, Sinclair JH, Alcami A. 2006. The UL144 gene product of human cytomegalovirus activates NFkappaB via a TRAF6-dependent mechanism. EMBO J. 25:4390-4399. http://dx.doi.org/10.1038/sj.emboj .7601287.

53. Le VT, Trilling M, Hengel H. 2011. The cytomegaloviral protein pUL138 acts as potentiator of tumor necrosis factor (TNF) receptor 1 surface density to enhance $\mathrm{UL} b^{\prime}$-encoded modulation of TNF- $\alpha$ signaling. J. Virol. 85:13260-13270. http://dx.doi.org/10.1128/JVI.06005-11.

54. Montag C, Wagner JA, Gruska I, Vetter B, Wiebusch L, Hagemeier C. 2011. The latency-associated UL138 gene product of human cytomegalovirus sensitizes cells to tumor necrosis factor alpha (TNF-alpha) signaling by upregulating TNF-alpha receptor 1 cell surface expression. J. Virol. 85:11409-11421. http://dx.doi.org/10.1128/JVI.05028-11.

55. Taylor RT, Bresnahan WA. 2006. Human cytomegalovirus IE86 attenuates virus- and tumor necrosis factor alpha-induced NFkappaBdependent gene expression. J. Virol. 80:10763-10771. http://dx.doi.org /10.1128/JVI.01195-06.

56. Allan-Yorke J, Record M, de Preval C, Davrinche C, Davignon JL. 1998 Distinct pathways for tumor necrosis factor alpha and ceramides in human cytomegalovirus infection. J. Virol. 72:2316-2322.

57. Davignon JL, Castanie P, Yorke JA, Gautier N, Clement D, Davrinche C. 1996. Anti-human cytomegalovirus activity of cytokines produced by CD4+ T-cell clones specifically activated by IE1 peptides in vitro. J. Virol. 70:2162-2169.

58. Pavić I, Polić B, Crnković I, Lucin P, Jonjić S, Koszinowski UH. 1993. Participation of endogenous tumour necrosis factor alpha in host resistance to cytomegalovirus infection. J. Gen. Virol. 74(Part 10):2215-2223. http://dx.doi.org/10.1099/0022-1317-74-10-2215.

59. Baillie J, Sahlender DA, Sinclair JH. 2003. Human cytomegalovirus infection inhibits tumor necrosis factor alpha (TNF-alpha) signaling by targeting the 55-kilodalton TNF-alpha receptor. J. Virol. 77:7007-7016. http://dx.doi.org/10.1128/JVI.77.12.7007-7016.2003.

60. Chan G, Bivins-Smith ER, Smith MS, Yurochko AD. 2008. Transcriptome analysis of NF-kappaB- and phosphatidylinositol 3-kinaseregulated genes in human cytomegalovirus-infected monocytes. J. Virol. 82:1040-1046. http://dx.doi.org/10.1128/JVI.00864-07.

61. Zhu H, Cong JP, Yu D, Bresnahan WA, Shenk TE. 2002. Inhibition of cyclooxygenase 2 blocks human cytomegalovirus replication. Proc. Natl. Acad. Sci. U. S. A. 99:3932-3937. http://dx.doi.org/10.1073/pnas .052713799 . 